\title{
A Dam Passage Performance Standard Model for American Shad
}

\begin{tabular}{|r|l|}
\hline Journal: & Canadian Journal of Fisheries and Aquatic Sciences \\
\hline Manuscript ID & cjfas-2018-0008.R1 \\
\hline Manuscript Type: & Article \\
\hline Date Submitted by the & 31 -May-2018 \\
\hline $\begin{array}{r}\text { Complete List of Authors: } \\
\text { Keyword: }\end{array}$ & $\begin{array}{l}\text { Stich, Daniel; State University of New York College at Oneonta, } \\
\text { Biology; Integrated Statistics } \\
\text { Sheehan, Timothy; Northeast Fisheries Science Center } \\
\text { Zydlewski, Joseph; Maine Cooperative Fish and Wildlife } \\
\text { Research Unit, }\end{array}$ \\
\hline $\begin{array}{r}\text { Is the invited manuscript } \\
\text { for consideration in a } \\
\text { Special Issue? : }\end{array}$ & $\begin{array}{l}\text { Not applicable (regular submission) } \\
\text { sapidissima }\end{array}$ \\
\hline \hline
\end{tabular}




\section{A Dam Passage Performance Standard Model for American Shad}

3 Daniel S. Stich*1, 2

$4 \quad{ }^{1}$ Biology Department and Biological Field Station, State University of New York College at

5 Oneonta, Oneonta, New York 13820, USA; ${ }^{2}$ Integrated Statistics, 16 Sumner St., Woods Hole, 6 Massachusetts 02543, USA.

7

8 Timothy F. Sheehan ${ }^{3}$

$9{ }^{3}$ National Oceanic and Atmospheric Administration, National Marine Fisheries Service, 10 Northeast Fisheries Science Center, 166 Water St., Woods Hole, Massachusetts 02543, USA;

11 email: tim.sheehan@noaa.gov.

12

13 Joseph D. Zydlewski ${ }^{4}$

$14{ }^{4}$ U.S. Geological Survey, Maine Cooperative Fish and Wildlife Research Unit and The

15 University of Maine Department of Wildlife, Fisheries, and Conservation Biology, Orono, Maine 16 04469, USA; email: josephz@maine.edu.

17

18 *Corresponding author (email: daniel.stich@oneonta.edu; phone: 1-607-436-3734; fax: 1-60719 436-3646) 
20 Abstract: Objectives for recovery of alosines commonly involve improving fish passage at dams

21 during migration. However, a quantitative basis for dam passage performance standards is

22 largely absent. We describe development of a stochastic life-history based simulation model for

23 American shad to estimate effects of dam passage and migratory delay on abundance, spatial

24 distribution of spawning adults, and demographic structuring in space and time. We used the

25 Penobscot River, ME USA as a case study to examine sensitivity of modelled population metrics

26 and probability of achieving specific management goals to inputs. Spawner abundance and

27 percent of repeat spawners were most sensitive to survival and migration delay at dams, marine

28 survival, and temperature cues for migratory events. Recovery objectives related to abundance

29 and spatial distribution of spawners were achievable under multiple scenarios, but high rates of upstream and downstream passage were necessary. The simulation indicated trade-offs between upstream and downstream passage efficacy whereby increased downstream passage was required

32 to maintain or increase population abundance in conjunction with increased upstream passage.

33 This model provides a quantitative support tool for managers to inform ecologically-based

34 decisions about a suite of management scenarios to facilitate recovery and sustainability of 35 diadromous fish populations. 


\section{Introduction}

The American shad, Alosa sapidissima, is an anadromous fish that spawns in the main-

45 stem of coastal rivers on the Atlantic coastal drainage of North America from the St. Johns River in Florida to the St. Lawrence River in Canada (Limburg et al. 2003). These fish migrate

47 upstream as adults to spawn, and the juveniles move downstream to the ocean in the fall.

Because these fish are iteroparous in the northern extent of their range, downstream migration of both juveniles and adults is important for population dynamics. Many populations of American shad are in decline throughout their range (Limburg and Waldman 2009; Hasselman and

51 Limburg 2012), and hydropower dams have been implicated as a causal factor in population

52 declines (Rulifson 1994; Limburg et al. 2003). Dams can cause acute mortality during both

53 downstream and upstream migrations (O’Leary and Kynard 1986; Kynard and O’Leary 1993).

54 Latent (sensu Nieland et al. 2015) or delayed mortality is also likely. Latent dam-related

55 mortality has been widely reported in salmonids in estuaries (Budy et al. 2002; Schaller et al.

56 2014, Stich et al. 2015a) and is likely to impact other migrating diadromous species. Likewise,

57 impedance of migration at dams has the potential to restrict distribution within a catchment and

58 access to spawning habitat (e.g., Grote et al. 2014a). Dams may also influence population

59 dynamics through delay. Delays at hydropower dams during both upstream and downstream migrations may result in elevated adult mortality in American shad due to exposure to predators

61 and energetic costs during long distances of migration (Castro-Santos and Letcher 2010).

63 of thermal conditions reflects the strong influence temperatures have on organisms. It is not

64 surprising that the arrival of adults in the river and the timing of spawning are strongly

65 influenced by temperature (Stier and Crance 1985). For American shad, biologically significant 
delays at dams may influence populations by restricting access to habitat, decreasing efficacy of spawners, or reducing the probability of post spawn survival. Fish with depleted energy reserves have reduced fitness (Nadeau 2007). For American shad any energetic costs of delay are not mitigated as these fish typically do not feed during their migrations (Limburg et al. 2003). Therefore, delays incurred at obstacles such as dams (as well as natural impediments) can reduce survival and recruitment, the components of individual fitness (Brett 1962; Rand and Hinch 1998; Naughton et al. 2005).

If delays at dams draw down critical energy reserves of migrants, the biological impact could be manifested in reproductive potential. For iteroparous species, there is the added risk to the capacity to return to spawn again in subsequent years. Thus, fish must not only reach their spawning habitat in time to spawn, but must maintain energy stores sufficient to return to the marine environment where they will recommence feeding and growth (Doucett et al.1999). The loss of repeat spawners may be symptomatic of the condition imposed by anthropogenic structures exemplified by the loss of older age classes of fish in the Connecticut River (e.g., Carscadden and Legget 1975).

Management actions considered or implemented for the recovery of alosine stocks on the Atlantic coast have included moratoria on directed ocean fisheries (Atlantic States Marine Fisheries Commission [ASMFC] 2010) and in-river fisheries (e.g., Olney and Hoenig 2001), supplementation stocking (e.g., Susquehanna River Anadromous Fish Restoration Cooperative [SRAFRC] 2010), bycatch reduction (Bethoney et al. 2014), and improvement of passage at migration barriers (Haro and Castro-Santos 2012). In Maine, USA, main-stem dams on both the Kennebec and Penobscot Rivers have been removed (Day 2006). In the Penobscot River, the Penobscot River Restoration Project (PRPP) was a catchment-wide effort with the goal of 
balancing hydropower production and diadromous fish conservation (Day 2006). Two lower river main-stem dams were removed in 2012 and 2013, and a nature-like fishway was constructed at a third in 2015. In addition to these changes, a fish elevator was installed at the now lowermost dam in the main-stem (Milford; Fig. 1). Assuming "safe, timely and effective passage,” (U.S. Fish and Wildlife Service and National Oceanic and Atmospheric Administration 2000), these changes have the potential to restore access to about $552 \mathrm{~km}$ of historic habitat for American shad (Trinko Lake et al. 2012), with an estimated production potential of 1.6 million spawning adults.(Maine Department of Marine Resources [MDMR] 2009).

State and federal fishery management agencies have identified the need to assess upstream and downstream passage at dams as part of the operational plan for rebuilding American shad stocks (MDMR 2009, ASMFC 2013). A basic question is central to regulatory decision makers; what level of passage is required to meet certain recovery goals? In the Penobscot River, the effectiveness of both the upstream and downstream passage in the river remains uncertain. There is a conspicuous absence of available tools to test performance scenarios in order to inform - and justify- performance standards at hydropower dams on this and other rivers. We sought to fill this need by developing a flexible modeling framework that would simulate the influence of passage performance criteria on American shad populations in a modeled system. To make this framework transferable among rivers, the model included i) path choices, ii) tributaries, and iii) multiple dams in addition to uncertainty in life-history parameters. We present the development and application of this model to the Penobscot River, a system which includes these structural complexities. We then use this model to test specific hypotheses related to passage efficacy and specific management goals associated with spawner abundance, demographics (proportion of repeat spawners), and distribution in the catchment. 


\section{Methods}

\section{Study site}

The Penobscot River (Fig. 1) is the largest river contained within Maine, USA, with a

116 drainage area of approximately $22000 \mathrm{~km}^{2}$. The river is tidally influenced from the mouth of the 117 bay inland to river kilometer (rkm) 45, a total distance of about $90 \mathrm{rkm}$ including the bay. At rkm

118 52, the river is divided into the main-stem Penobscot River on the east side of Marsh Island and 119 the Stillwater Branch to the west. At rkm 100, the largest tributary to the Penobscot River, the 120 Piscataquis River, enters the main-stem. Spawning habitat for American shad begins in tidal

121 freshwater and extends beyond the most upstream dams in both the main-stem Penobscot River 122 and the Piscataquis River (Fig. 2). The majority of spawning habitat is located in the main-stem 123 between Milford and Weldon dams, with about 50\% of the total production potential located on 124 either side of West Enfield Dam (Table 1).

Currently, there is no volitional upstream passage for American shad at Orono Dam, 126 located on the confluence in the Stillwater Branch (Fig. 1). A small fish trap, collects American 127 shad and river herring (alewife A. pseudoharengus and blueback herring A. aestivalis) that 128 subsequently are trucked beyond the head of the Stillwater Branch to the main-stem Penobscot 129 River (NMFS 2012b). There remains the potential that fish might be attracted to the tailrace of 130 Orono Dam and incur migratory delay. Upstream fish passage at Milford Dam (rkm 60) occurs 131 primarily via a newly constructed fish elevator (Federal Energy and Regulatory Commission 132 [FERC] 2009).

133 Downstream passage for both juveniles and adults around Marsh Island occurs either 134 through the main-stem or the Stillwater Branch. Proportional passage through these routes during 
downstream migration was dependent upon discharge for downstream-migrating Atlantic salmon Salmo salar (Stich et al. 2014), and the proportion of fish using the Stillwater Branch for downstream migration is expected to range from 6 to 25\%. In the main-stem, Milford Dam is the only barrier to downstream migration. Fish migrating downstream through the Stillwater Branch navigate both Stillwater and Orono dams before rejoining the main-stem (Fig. 1).

At the confluence of the Penobscot and Piscataquis rivers, upstream migrants may either continue in the main-stem and approach West Enfield Dam or enter the Piscataquis River via a nature-like fishway which bypasses Howland Dam. Migrants in the Piscataquis River may pass as many as three additional dams before reaching the upstream extent of spawning habitat. Migrants successfully passing West Enfield Dam may pass only one other dam (Weldon) before reaching the upstream extent to spawning habitat in the main-stem of the river. Upstream migration path at the confluence is also proportional to discharge from the upper river in Atlantic salmon, and changes in flow might even override homing to the Piscataquis River (Gorsky et al. 2009). For the purpose of this study, we assumed that probability of using these two migration paths was proportional to the production potential in the corresponding river sections (Table 1).

\section{Model overview}

We used a simulation approach to modeling life history and migration of American shad in the Penobscot River to assess the effects of passage rates and migration delays at dams on population abundance and demographic structuring through time and space. To facilitate this, we divided the river into spatially explicit production units (PU) based on the locations of dams in the catchment (Fig. 1) and assigned production potential in each PU (Fig. 2) using data from 
157 MDMR (2009). The model was spatially structured based on these units and the four potential 158 migration routes for upstream and downstream migration (i-iv, Fig. 2).

The model was a combination of a classical, cohort-based projection model for

160

161

162

163

164

165

166

167

168

downstream migration and marine survival, with an annual time-step and an individual-based upstream migration model with temporal (daily) and spatial $(1 \mathrm{~km})$ components (Fig. 3). The approach taken was like the state-based Dam Impact Analysis (DIA) developed by Neiland et al. (2015), but we replaced the state-based approach to upstream migration with a spatially and temporally explicit individual-based model similar to that developed by Castro-Santos and Letcher (2010). The rationale for this approach was that there currently is little evidence of homing or sub-catchment population structuring in American shad populations in the Gulf of Maine or elsewhere (Hasselman et al. 2010).

The model was initialized by creating an age-structured starting population of American shad in the ocean based on ocean mortality rates and a range of starting population sizes (Table 2; ASMFC 2007). From this starting population, an age structured ‘spawning pool’ was drawn based on the probability of recruiting to spawn at each age and age-specific probabilities of repeat spawning (Bailey and Zydlewski 2013). All fish remaining in the ocean during the spawning season were assigned to the 'recruitment pool.' Those fish that matured and entered the spawning pool were assigned an age, sex, length, mass, fecundity (for females), and optimal ground speed (as described below). We then modeled fish migrating upstream as individuals during each annual spawning run (Fig. 4).

Based on the lack of assumptions about homing, the timing of major phenological events within the model (e.g., river arrival and spawning dates) were dictated by thermal experiences of fish, and incorporated both inter- and intra-annual variability in thermal regimes based on 
180

181

182

183

184

185

186

187

188

189

190

191

192

193

194

195

196

197

198

199

200

201

202

historical and contemporary data. Movement throughout the system was further limited by efficiency and timing of dam passage. River arrival, in-river movements, and spawning location were characterized for each fish based on individual fish characteristics parameterized using literature values and available data. Individual river arrival ('dArrival ${ }_{j}$ ') and spawning date $\left(\mathrm{dSpawn}_{j}\right)$ were assigned based on modeled river temperature. The probability of an individual fish arriving at discrete reaches between dams (production units; PUs as defined in section 2.3.1) was based on a priori individual assignments (e.g., length) in conjunction with: i) environmental conditions, ii) physical constraints, iii) pre-determined migratory paths, iv) upstream passage efficiencies, and delays below main-stem dams (Fig. 3). In a given PU, adult fish incurred a natural, pre-spawn mortality and female fish spawned some number of eggs. The juvenile survival of those fertilized eggs was subsequently limited by habitat constraints (carrying capacity) between dams (Fig. 2). The number of fish at each age (including juveniles) was then summed in each PU.

We used a cohort-based approach for downstream migration of juveniles and adults that treated fish as sex- and age-specific groups. The number of adult and juvenile fish from each cohort reaching the ocean was based on: i) the PU in which fish initiated downstream migration, ii) the probability of using a given downstream migration route, iii) acute mortality at dams encountered in each migratory route, iv) indirect cumulative effects of dam passage in fresh water, and v) indirect latent effects of dams during estuary passage. The number of post-spawn adults surviving to the ocean in each age class was retained in the spawning pool for the next year, with 100\% retention in the spawning pool after first spawn (Bailey and Zydlewski 2013). Juvenile out-migrants were added to the recruitment pool. A projection matrix was then used to apply ocean mortality rates (Table 2) to the spawning pool and to the recruitment pool, and to 
203

204

205

206

207

208

209

210

211

212

213

214

215

216

217

218

219

220

221

222

223

224

225

graduate each cohort to the next age-class (Fig. 3). We then used age-specific probabilities of recruitment to spawn to re-allocate age-specific proportions of the recruitment pool to the current spawning pool and start the next year of the simulation, similar to how the initial spawning pool was developed. Each iteration of the simulation was repeated for 50 years.

\section{Model inputs}

All input parameters (Table 2) for this model were calibrated using field or laboratory data from the literature or from collaborating agencies. The modeling approach was stochastic and thus incorporated uncertainty in input parameters, either through estimated precision of empirically derived parameters or by imposing a wide range of potential values over pointestimates where no estimate of precision was available. We randomly sampled values for input parameters at appropriate scales (across years, or within years) from statistical distributions. We used Monte Carlo simulation to incorporate this variability within the model stochastically, repeating the 50-year simulation 50000 times. For the sake of consistency in model notation, we refer to individuals using the subscript $j$, fish ages using subscript $i$, fish sex using the subscript $s$, days using subscript $d$, years using subscript $t$, and production units using the subscript $n$.

\section{Hydro system characteristics and environmental data}

We defined a PU as the contiguous habitat for American shad above or below dams in the catchment (Fig. 1). Following the activities associated with the PRRP, nine FERC-regulated hydropower dams remain between the mouth of the Penobscot River and the estimated upstream extents of American shad spawning habitat in the Penobscot and Piscataquis rivers. The extent of the most-upstream PU in the Penobscot and Piscataquis rivers was defined by the upstream 
226

227

228

229

230

231

232

233

234

235

236

237

238

239

240

241

242

243

244

245

246

247

248

extent of American shad habitat in each river (Trinko Lake et al. 2012). In the Piscataquis River, the extent of upstream habitat for American shad above Guilford Dam was beyond rkm 185 (Fig. 1). In the main-stem Penobscot River, the upstream extent to American shad habitat above Weldon Dam was considered to have been reached at rkm 165 because all production beyond that occurred within the same PU (Fig. 1). The lower-most production unit began in tidal freshwater portions of the Penobscot River at rkm 40 (Fig. 1). We calculated expected production potential for each PU based on the total production potential of various sub-units within each PU as laid out in the Operational Plan for the Restoration of Diadromous Fishes to the Penobscot River (Table 1; MDMR 2009).

We collected mean daily temperature data within the Penobscot River from the U.S. Geological Survey (USGS) gauge in Eddington (station ID 01036390), Maine at rkm 45 using the 'waterData' package (Ryberg and Vecchia 2014) in R (R Core Team 2016). We only used data from recent years during which complete data were available (years 2007-2014) to improve the quality of the data used and to avoid using historical data that spanned beyond recent, abrupt changes in global climate (e.g., 1980s regime shift noted by Reid et al. [2016]). We then used those data to simulate mean daily temperatures in the catchment for each year the model was run (Fig. 5). To incorporate uncertainty due to annual variability within this process, we randomly sampled year from a uniform categorical distribution. We then simulated daily temperatures $\left(d T^{2} p_{t}\right)$ for each year $t$ by drawing values from a random, multivariate normal distribution based on the mean temperature on each day and the covariance with other dates using the 'MASS’ package (Venables and Ripley 2002) in R (R Core Team 2016). To speed computation, we drew a single value for each day in each year. This resulted in some missing values due to the nature of random sampling from a multivariate normal distribution (not all days are sampled 
249

250

251

252

253

254

255

256

257

258

259

260

261

262

263

264

265

266

267

268

269

270

271

each time, and some are sampled more than once). Therefore, we used a cubic spline interpolation to estimate temperatures for those days that were not sampled using the 'zoo' package (Zeileis and Grothendieck 2005) in R (R Core Team 2016). Simulated temperatures appeared to follow contemporary patterns reasonably well, so we were satisfied that the approach produced representative patterns in temperature.

Because much of the data used in this model were from the Connecticut River, we used temperature data from the Connecticut River to calibrate phenological events in our analyses to account for latitudinal variability and differences in photoperiod cues between locales. We then used linear regression to relate temperatures in the Connecticut River and the Penobscot River so that we could use temperature in the Penobscot River to simulate life-history components of the model such as the date of arrival in the estuary and dates used to define spawning windows based on relationships with temperature. Daily water temperatures in the lower Connecticut River were available from the USGS gauge at Hartford, CT (station ID 01129500) using the 'waterData' package (Ryberg and Vecchia 2014) in R (R Core Team 2016), and mean daily water temperatures for upstream reaches of the Connecticut River (Turners Falls, MA) for the period 1994-2016 were provided by the USGS (T. Castro-Santos, USGS, S.O. Conte Anadromous Fish Research Lab, Turners Falls, MA, unpublished data).

\section{Spawning pool structure}

We simulated a starting population of American shad in the Penobscot River by starting with a simulated abundance age-1 American shad and applying a marine survival rate to that cohort over the maximum lifespan to calculate the total abundance of fish at each age $i$ in the first year $t$ of the simulation $\left(N_{i, \mathrm{t}=1}\right)$ and arrive at an age-structured population of fish in the 
272 ocean. The current abundance of American shad in the Penobscot River is unknown. In 2016, 273 more than 8000 American shad passed the fish lift at Milford Dam, and only a small fraction of

274 fish that were tagged at the head of tide were ever detected approaching the dam (G. Maynard, 275 The University of Maine, unpublished data). As a result, a minimum population estimate of 276 approximately 10000 fish (Grote et al. 2014b) was assumed as a starting value, but we note that 277 this is likely a conservatively low estimate, and thus incorporated variability in this parameter.

278 Therefore, we chose a random starting abundance of age- 1 fish $\left(N_{i=1, t=1}\right)$ to seed the population 279 from a Poisson distribution with $\lambda=10$ 000. We assumed an age-invariant marine survival rate 280 of 0.62 for American shad at each age $\left(S_{M, i}=0.62\right)$ in the Northeast (ASMFC 2007) to project 281 this starting population until the maximum age (9 years) was reached. Although the structure of 282 the model is such that it allows for age-specific marine survival rates, we applied the same rate to 283 all age classes for lack of more specific information. To incorporate uncertainty in the current 284 state of knowledge about marine survival for this species, we randomly sampled annual marine 285 survival rates from a beta distribution with parameters $\alpha=12$ and $\beta=8$. This resulted in a left286 skewed distribution with a mean marine survival rate of 0.60 (range $\approx 0.15-0.95$ ). We applied an 287 invariant rate mortality estimated from the method of Hoenig (1983) using a cohort-based 288 projection matrix:

$$
N_{i, t=1}\left(\prod_{i=2}^{9} S_{M, i}\right) \times N_{i=1, t=1}
$$
We used age-specific probabilities of recruitment to first spawn $R F_{i}$ from Bailey and 292 Zydlewski (2013) to calculate the number of first-time spawners in our starting population. To 
293

294

295

296

297

298

299

300

301

302

303

304

305

306

307

308

309

310

311

312

313

314

increase flexibility in the modeling approach, we included variable probability of recruitment to subsequent spawning events for each age class conditional on survival $R S_{i}$. However, for the purpose of this effort, we set $R S_{i}$ equal to 1.00 for all ages modeled. For each year $t$ after the initial year, we used annually varying $S_{M, i, t}$ to calculate the number of fish from each age class

(i) within the recruitment pool $\left(N R_{i, t}\right)$ surviving from year $t$ that were added to the spawning pool in year $t+1\left(N S_{i, t+1}\right)$ using a series of element-wise vector operations:

(2)

$$
N S_{i, t+1}=\left(\left[\begin{array}{c}
N R_{i=1, t} \\
\times S_{M, i=1, t} \\
\vdots \\
N R_{i=9, t} \times S_{M, i=9, t}
\end{array}\right] \circ\left[\begin{array}{c}
R F_{i=1} \\
\vdots \\
R F_{i=9}
\end{array}\right]\right)+\left(\left[\begin{array}{c}
N S_{i=1, t} \times S_{M, i=1, t} \\
\vdots \\
N S_{i=9, t} \times S_{M, i=9, t}
\end{array}\right] \circ\left[\begin{array}{c}
R S_{i=1} \\
\vdots \\
R S_{i=9}
\end{array}\right]\right)
$$

\section{Arrival and spawning dates}

We simulated individual, spawning fish $(j)$ based on the number of fish in each age class $i$ in the spawning pool during a given year $\left(N S_{i, t}\right)$. Sex ratio of American shad entering the Penobscot River is not well characterized, so we assumed that sex ratio approached 1:1 in most years (Bailey and Zydlewski 2013). To incorporate uncertainty in the sex ratio of fish, we randomly assigned sex to each $j^{\text {th }}$ fish using a Bernoulli trial with probability of being female (i.e., success) determined from a beta distribution with $\alpha=100$ and $\beta=100$. This distribution has a mean, annual probability of being female ( $p$ Female $_{t}$ ) equal to 0.50 for any given individual, but allows for divergence from an even sex ratio in the population (range $\approx 0.30-0.70$ ).

We assigned individual arrival dates (dArrival $\left.{ }_{j}\right)$ and terminal spawning dates for individual fish based on simulated daily temperatures in the Penobscot River and empirical relationships between arrival date and accumulated thermal units (ATU: from January 1 to harvest date) in the Connecticut River. We related cumulative proportion of catch by commercial 
fishers in the lower Connecticut River (Connecticut Department of Energy and Environmental Conservation [CTDEEP], unpublished data) to ATU using sex-specific logistic regression models that included an over dispersion parameter. We found that ATU was a strong predictor of cumulative harvest in the lower Connecticut River (McFadden's pseudo $R^{2}=0.985$ ). We used this model to predict probabilities of arrival in the mouth of the Penobscot River each day using ATU calculated from simulated temperatures after establishing a relationship between temperatures in the Penobscot River and the Connecticut River (linear regression, $R^{2}=0.976, F$ $\left.=8.4 \times 10^{4}, \mathrm{df}=2051, p<0.001\right)$. We incorporated variability in this relationship by bootstrapping the regression fit 1000 times for each sex using 90\% of the data each time, saving parameter values for each regression. These parameter values were then randomly sampled for each year $t$ and used to predict cumulative probability of arrival by American shad in the Penobscot River each day based on simulated ATUs. The ATUs used in this study resulted in spawning dates from late May through late July, which roughly correspond to dates from previous work in this system (Grote et al. 2014a). As information about arrival in the system improves, these values can be tuned in the model, but this range was thought to be sufficient for the purpose of simulation as all phenological events were temperature-driven.

For each individual American shad, we used a Bernoulli distribution (with probability of success equal to date-specific arrival probabilities) to predict the first temperature (tArrival $\left.{ }_{j}\right)$ and date on which each $j^{\text {th }}$ fish arrived in the river $\left(\right.$ dArrival $\left._{j}\right)$. We assumed that initiation of spawning by individuals occurred after river arrival and was regulated by ATU experienced following A $_{\text {Arrival }}$. The ATU at which spawning initiated for each individual ( $t$ Spawn INITIAL, $j$ ) was randomly drawn from a normal distribution $(150 \pm 15$, mean \pm SD) based on expert opinion. Similarly, the termination of spawning was assumed to be regulated by cumulative thermal 
350

351

$$
L_{j}=L_{\infty_{s}} \times\left(1-e^{-k_{s} \times\left[t_{j}-t_{0_{s}}\right]}\right)
$$
corresponding to the York River in Virginia (Olney et al. 2006).

\section{Individual fish characteristics} Bertalanffy growth function (von Bertalanffy 1938): Hightower (2014) using:

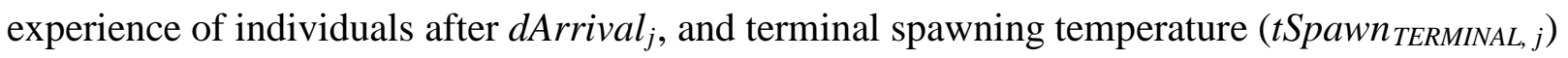
and date were assigned based on ATUs drawn randomly for each individual from a normal distribution $(500 \pm 15$, mean \pm SD) which were also selected based on expert opinion. Though information from the Penobscot River is absent for comparison, this procedure resulted in a distribution of residence times (RT) that were consistent with the range of published estimates

Because of relationships between fish size, swimming ability, and fecundity, we assigned fork length of individual fish $\left(L_{j}\right)$ dependent upon their age (i) and sex (s) using the von

where $L_{\infty_{s}}$ is the sex-specific theoretical maximum length of fish, $k_{s}$ is sex-specific Brody growth coefficient, $t_{0_{s}}$ is the sex-specific time at which fish length was theoretically zero, and the variable $s$ can take on values of 'MALE' or 'FEMALE'. We estimated von Bertalanffy growth parameters using 16947 lengths at age for American shad in the Connecticut River 2010-2014. We randomly sampled 1000 individuals of each sex to estimate sex-specific growth parameters during each iteration of the simulation to incorporate uncertainty. We predicted the mass $\left(m_{j}, \mathrm{~g}\right)$ of each fish using sex-specific parameters for length-mass relationships defined by Raabe and 


$$
m_{j}=\alpha_{s}+\beta_{s} \times L_{j}
$$

where $\alpha_{s}$ is the intercept, $\beta_{s}$ is the slope of a linearized relationship between $m_{s}$ and $L_{j}$, and the variable $s$ can take on values of 'MALE' or 'FEMALE'. Note that because these variables were not linked to any simulated ecological processes or model outputs at the time of writing, sensitivity was not assessed. However, they were included both as inputs and in output files for use in the future should reliable estimates of mass-fecundity relationships be established.

372 each female, we used a Bernoulli trial to assign spawning history (repeat or virgin) with

373 conditional probability of being a repeat spawner (i.e., success) given age in the first year (IpR).

374 For all subsequent years, the age-specific probability of repeat spawning was calculated directly

375 based on the observed number of fish surviving to spawn in the simulated fish population

376 (spawning pool) after the first year. We randomly sampled mean BF for each fish from a

377 conditional negative binomial distribution with parameters specific to virgin $(\mu=20000, \theta=10)$

378 and repeat spawners $(\mu=30000, \theta=10)$. The values drawn from these distributions closely

379 approximated the means and ranges of batch fecundities for virgin and repeat spawners reported

380 by Hyle et al. (2014). We note that an alternative approach would have been to randomly assign

381 the number of eggs in each batch for each fish from these distributions rather than using a mean

382 batch fecundity for each fish. However, we were conservative in our inclusion of uncertainty

383 within these estimates based on expert consensus, and thus elected not to incorporate uncertainty 
384 in parameterization at the individual level. We calculated $R T_{j}$ as the time elapsed in days

385 between arrival date and terminal spawning date (both based on temperature) for each female.

386 We randomly sampled $S I_{j}$ for each female from a normal distribution with $\mu=2.49$ days, and SD

$387=0.27$ days (Hyle et al. 2014). Realized annual fecundity $\left(R A F_{j}\right)$ was calculated for each fish in

388 their final PU as:

$$
R A F_{j}=\left\{\begin{array}{l}
B F_{V, j} \times\left(\frac{R T_{j}}{S I_{j}}\right), B F_{j}=B F_{V, j}, \\
B F_{R, j} \times\left(\frac{R T_{j}}{S I_{j}}\right), B F_{j}=B F_{R, j}
\end{array}\right.
$$

\section{Upstream migration model}

We developed an individual-based model of upstream migration for American shad based

397 in addition to potential delays at other features of interest (e.g. at the confluence of the main-stem

398 Penobscot River and the Stillwater Branch). Furthermore, because little or no reliable

399 information exists with respect to sub-watershed homing tendencies of American shad, we

401 computations involved with this process and reduce overhead costs of running the model, the

402 individual-based migration model was pre-compiled in the $\mathrm{C}++$ programming language and

403 integrated into the life-history based model using the 'Rcpp' package (Eddelbuettel and Francois

404 2015) in R (R Core Team 2016). Population abundance was dynamically scaled within the model 
405

406

407

408

409

410

411

412

413

414

415

416

417

418

419

420

421

422

423

424

425 426 dam.

each year by factors of 10 to reduce the maximum number of fish being run through the individual-based model in a given year to several thousand rather than several million. Additional reductions in the time required to run models were achieved through the use of parallel processing on the high-performance computing cluster at the University of Buffalo Center for Computational Research.

The upstream migration model was programmed in a spatially and temporally explicit manner. It was run on a daily time-step from the minimum of $d$ Arrival $_{j}$ to the maximum of $d S p a w n_{j}$ for each year of the simulation, and from the mouth of the river to the upstream extent of spawning habitat. On each day of the annual upstream migration, the program queried individual fish to determine if a fish could move that day based on $d A_{r r i v a l}, d \operatorname{Spawn}_{j}$, and the current location of the fish with respect to the maximum upstream extent of American shad habitat $(\operatorname{maxRkm})$ in that fish's migratory route (Fig. 4). Given that these conditions were satisfied, the program then assessed passage with respect to hydro-system characteristics and passage efficiencies in each 1-kilometer reach of river that a fish could move in a single day up to an individual daily maximum for movement rate (section 2.3.7). This was done using a random draw from a Bernoulli distribution with probability of passage (i.e., success) equal to passage efficiency for that reach (Fig. 4). For free-flowing river reaches, passage efficiency was assumed to be 1.00. Passage efficiency in reaches containing dams was based on the probability of passing a dam during a given time period (expressed as a proportion of $24 \mathrm{~h}$ ). Thus, passage rates at dams incorporated both effectiveness (probability of passage) and timeliness (the period over which passage was achieved) elements. Each fish was allowed one attempt per day to pass a 

446 River.

\section{Migration routes}

The individual-based, upstream migration model accommodated inclusion of multiple upstream migration routes to increase the flexibility of the underlying model and improve transferability between systems. The use of each migration route by individual fish was determined based on a priori, probabilistic rules (e.g., proportional flow around islands or proportional production potential at major tributaries). In theory, the number of migration routes used is not limited, but a greater number of routes would increase model complexity and time required to run model simulations.

We modeled four possible upstream migration routes (Table 1) for American shad from the estuary to the upstream extent of spawning habitat in the main-stem Penobscot and Piscataquis rivers (i-iv in Fig. 2). One of these four migration routes was assigned to each individual fish from a categorical distribution prior to initiation of upstream migration each year of the simulation. The four categories included all combinations of two migration routes around Marsh Island in the lower river and each of two migration routes at the confluence of the Penobscot and Piscataquis rivers: i) main-stem Penobscot River around Marsh Island and the Piscataquis River, ii) Stillwater Branch around Marsh Island and the Piscataquis River, iii) mainstem Penobscot River around Marsh Island and the main-stem Penobscot River, and iv) migration through the Stillwater Branch around Marsh Island and the main-stem Penobscot

The probability of using a given upstream passage route was conditional on relative discharge from the Stillwater Branch and main-stem Penobscot River around Marsh Island, but was proportional to differences in production potential upstream of West Enfield Dam (mainstem Penobscot River) and Howland Dam (Piscataquis River, Fig. 2). Our rationale for this 
451 approach was that the Stillwater Branch presented minimal habitat with regard to population 452 productivity, but had the potential to attract migrating fish based on a flow diversion from the 453 main-stem Penobscot River.

The maximum allowable flow diversion to the Stillwater Branch is $40 \%$ of total river discharge (FERC 2004a). We made the simplifying assumption that flow diversion was uniformly distributed during the shad run each year, and that diversion ranged from 0.10 to 0.40

457 between years. As such, the annual marginal probability of using the Stillwater Branch for upstream migration $\left(\psi_{\text {STILLUP, }}\right)$ was drawn from a uniform distribution in the interval $[0.10,0.40]$ each year to indicate that migratory route was proportional to flow. All fish arriving at the Orono Dam (i.e., those that used the Stillwater Branch) were automatically passed beyond Gilman Falls 461 in the model, because current practice is to truck American shad from Orono Dam to the Milford 462 Dam head pond. Likewise, the annual probability of an individual fish using the Piscataquis 463 River $\left(\psi_{\text {PISCUP, }}\right)$ for upstream migration was drawn from a uniform distribution in the interval $464[0.30,0.50]$ based on production potential upstream of West Enfield and Howland dams. Using marginal probabilities of migration through the Stillwater Branch and the

466 Piscataquis River, the joint probabilities of using each of the four migration routes in the river 467 (Fig. 2) were calculated as: i) Stillwater Branch to Piscataquis River: $\left(\psi_{\text {STILLUP,t }} \times \psi_{\text {PISCUP,t }_{, t}}\right)$,ii) 468 Stillwater Branch to main-stem: ( $\left.\phi_{\text {STILLUP,t }} \times\left[1-\phi_{\text {PISCUP,t }}\right]\right)$, iii) main-stem to Piscataquis 469 River: $\left(\left[1-\psi_{\text {STILLUP, }}\right] \times \psi_{\text {PISCUP }, t_{t}}\right)$, and iv $)$ main-stem to main-stem: $\left(\left[1-\psi_{\text {STILLUP, }} \times\right.\right.$ $\left.470\left[1-\psi_{P I S C U P, t}\right]\right)$. An upstream migration route was thus assigned to each fish probabilistically, 471 prior to river arrival. However, movement through each rkm within these migration routes was 472 dependent upon AArrival $_{j}, d$ Spawn $_{j}$, individual movement rates, and passage efficiencies at 
473 dams. Therefore, it was possible (for example) that a fish assigned to the Piscataquis River

474 would never actually pass Howland Dam (or any other) based on variation in other overriding 475 factors.

476

477

478

479

480

481

482

483

484

485

486

487

488

489

490

491

492

493

494

495

\section{Upstream movement rates}

Theoretical daily movement rates were calculated for each fish based on fork length estimated from von Bertalanffy growth models $\left(L_{j}\right)$, movement tortuosity (i.e., degree of wandering), and ground speed. First, we defined a maximum daily movement rate for each fish as the maximum distance that was theoretically possible for each fish to move in a day given unimpeded passage through the river and unidirectional movement upstream over a 24-hour period. This maximum daily movement rate in $\mathrm{km}$ for each fish $\left(\mathrm{dMax}_{j}\right)$ was calculated as:

$$
\operatorname{dMax}_{j}=L_{j} \times \text { sOptim }_{j}
$$

where $L_{j}$ is individual fork length, $s O p t i m_{j}$ is optimizing ground speed for each fish. The variable sOptim $_{j}$ was drawn for each fish from a uniform distribution between 0.7 and 1.7 body lengths per second $\left(\mathrm{bl} \cdot \mathrm{s}^{-1}\right)$ to maintain consistency with previous work (Castro-Santos and Letcher 2010). We made the assumption that the majority of this movement occurred during hours of day light (Haro and Castro-Santos 2012). We also assumed that movement of American shad did not occur in a straight line (Castro-Santos and Letcher 2010), to incorporate effects of observed behaviours such as meandering during migration (Bailey et al. 2004) or milling at barriers (Grote et al. 2014b). In recognition of these assumptions, we adjusted $d M a x_{j}$ by the proportion of each day $(d)$ that comprised hours of daylight $\left(p D_{a y}\right)$ and a tortuosity parameter that allowed for 
496

497 498

499

500

501

502

503

504

505

506

507

508

509

510

511

512

513

514

515

516

517

518

reduction in upstream migration rates due to deviation from straight-line movements $\left(\right.$ tort $\left._{j}\right)$ to arrive at a realized daily movement rate for each fish $\left(\mathrm{dReal}_{j}\right)$ :

$$
d \operatorname{Real}_{j}=d \operatorname{Max}_{j} \times p \operatorname{Day}_{d} \times \text { tort }_{j}
$$

For each fish, tort $_{j}$ was a unitless value drawn from a random uniform distribution between 0.2 and 1.00 , thus allowing for reductions in daily movement rate from zero to $80 \%$ to incorporate uncertainty and align with values used in previous studies (Castro-Santos and Letcher 2010). The proportion of day light hours in a twenty-four hour period $\left(p D a y_{d}\right)$ was estimated as the mean of photoperiod (in hours) during the migration divided by 24 hours for each year of the simulation. The 'migration', for this purpose, was defined as the entire period between the minimum of $d$ Arrival $_{j}$ through the maximum of $d \operatorname{Spawn}_{j}$. Photoperiod was calculated using the geosphere package (Hijmans 2016) in R (R Core Team 2016) based on day of year and latitude at Milford Dam.

We incorporated a seasonally varying reduction in movement rate due to theoretical, temporal changes in "motivation” (see Agostinho et al. 2007) during the spawning migration due to lack of assumptions about homing in the model. We assumed that fish were most highly motivated to move upstream early and at the peak of the run based on bio-energetic constraints at the end of the season (Castro-Santos and Letcher 2010). This assumption was based on observed changes in relationships between timing of arrival at subsequent dams in the Connecticut River with respect to ATU (Ken Sprankle, US Fish and Wildlife Service, unpublished data). Based on those changes, we assumed that motivation was inversely proportional to ATU and was assigned as an individual-based penalty $(j)$ that was multiplied by passage efficiency in each reach and 
519

520

521

522

523

524 where motivation $_{j, d}$ was the penalty, $\mathrm{ATU}_{j, d}$ was the ATU experienced by individual $j$ on day $d$, 525 and the minimum and maximum ATU were probabilistically determined for each fish based on 526 that changed based on ATU each day $(d)$, and the minimum and maximum ATU realized during each spawning season:

$$
\text { motivation }_{j, d}=\frac{1-\left(\mathrm{ATU}_{j, d}-\min \left[\mathrm{ATU}_{j}\right]\right)}{\left(\max \left[\mathrm{ATU}_{j}\right]\right)}
$$
this relationship in the model will remain subjective until better data become available. As such, the motivation penalty currently constitutes only a minor reduction in individual fish movement through the system; however its inclusion in the model may be important for future applications.

\section{Spawning dynamics}

We extracted the final rkm for each fish from the individual-based migration model and assigned each fish to a PU based on distance traveled (in rkm) and migration route. Following assignment to a PU, adults were allowed to survive the pre-spawn period with a sex-specific annual survival probability $\left(S_{P R E, t, s}\right)$, and all females spawned all eggs from realized annual fecundity of individuals $\left(R A F_{j}\right)$ within that PU. The number of eggs deposited in each PU was summed. We assumed that, at carrying capacity, American shad saturate spawning habitat with eggs even at minimal individual fecundity as an evolutionary strategy for coping with environmental stochasticity, year-class failure, etc. Therefore, we assumed a density-dependent process and capped egg production in each $n^{\text {th }}$ PU by assigning a carrying capacity $\left(k P U_{n}\right)$ to each PU based on PU-specific production potential $\left(p P U_{n}\right)$, and the lower 95\% confidence limit 
$542\left(Q_{0.025}\right)$ of $R A F$ among all females for a given year, and the number of females in each PU $543\left(f P U_{n}\right)$ as:

544

545

$$
k P U_{n}=p P U_{n} \times f P U_{n} \times Q_{0.025}
$$

546

547

Post-spawning dynamics and downstream migration

549

550

551

552

553

554

555

556

557

558

559

560

561

562

At the completion of spawning, adult fish within each PU were grouped as post-spawners (grouped separately as males and females within age classes). We summed the sex-specific number of fish in each PU by age for each of the four migration routes. We incorporated postspawning survival $\left(S_{P O S T, t, s}\right)$ rate as occurring in all production units. The general structure of the model allowed for separate $S_{P O S T, t, s}$ for males and females. In the Penobscot River model we assigned $S_{P O S T, t, s}$ values each year of the simulation for both sexes using a beta distribution with $\alpha=200$ and $\beta=50$, resulting in a left-skewed distribution with a mean of about 0.80 (95\% CI:

0.79-0.87), which approximately covered the range of spawning-season survival estimated in the Little River, North Carolina (Raabe and Hightower 2014).

Juvenile survival from egg to out-migration remains a highly uncertain life-history vital rate for American shad, although it is widely held that juvenile survival is low during this period relative to other life stages (Savoy et al. 2004). Survival rates of 0.00056-0.00083 were reported for the egg-to-juvenile life stage for American shad in the Connecticut River (Leggett 1977). To incorporate this uncertainty, we drew juvenile survival $\left(S_{J U V,}\right)$, each year from a random uniform distribution from 0.00056 to 0.00083 .

Following application of post-spawning dynamics, all fish were moved downstream in age-structured cohorts from each PU using a state-based approach. Downstream survival rates 
565 were determined by setting dam-passage performance standards at each dam in each of four

566 possible downstream migration routes (described below). All mortality incurred during

567 downstream migration was additive with respect to post-spawning survival dynamics (i.e.,

568 natural mortality), and was incurred as a result of dam passage or indirect mortality (e.g.,

569 predation). This mortality was accounted for in three parts within the model: i) acute mortality at

570 dams (measured by passage performance standards), ii) indirect mortality $\left(M_{I}\right)$ in fresh water

571 below dams, and iii) latent (delayed) mortality $\left(M_{L}\right)$ during estuary passage. Indirect and latent

572 mortality were cumulative in that fish passing more dams experienced lower absolute probability

573 of reaching the ocean in a given year than those passing fewer dams. We applied these mortality

574 rates as proportional reductions to downstream survival rates within the general model structure,

575 however these values were set at zero for this demonstration due to lack of reliable information.

576 The model allowed for separate dam-passage survival rates for adult and juvenile fish. For this

577 study, downstream survival at dams varied uniformly from 0.00 to 1.00 by increments of 0.10 .

578 Adult and juvenile downstream survival rates were set to be the same within the model, and

579 downstream survival at dams was held constant at all facilities in the watershed.

580 Both post-spawn adults and juveniles followed one of four routes. Assignments were

581 made in a similar fashion to upstream movement; however, the starting PU limited the number of

582 pathways for fish. There were four potential migration routes that could have been used by

583 American shad in the Penobscot or Piscataquis rivers during seaward migration, congruent with

584 the upstream migration routes. Out-migrants from either the Piscataquis River or the upper main-

585 stem Penobscot River could move through either the Stillwater Branch or the lower main-stem

586 Penobscot River around Marsh Island during seaward migration. As with the upstream migration

587 model, we assumed the probability of a fish using the Stillwater Branch for seaward migration 
588

589

590

591

592

593

594

595

596

597

598

599

600

601

602

603

604

605

606

607

608

609 was approximately proportional to flow distribution around Marsh Island. Previous studies of downstream migration in other species indicate that about 12\% (95\% CRI: $11-13 \%)$ of fish use this migration route during spring outmigration (Stich et al. 2015b). In the absence of speciesspecific, and life-stage specific information about use of these routes by American shad, we assumed that these relationships were similar. And, even though adult and juvenile American shad migrate at different times, and thus experience different flows, we made the simplifying assumption that proportional use of the Stillwater Branch was similar between life stages. Therefore, the probability of using the Stillwater Branch during downstream migration $\left(\psi_{S T I L L D, t}\right)$ was randomly drawn from a beta distribution with $a=50$ and $b=300$, allowing for greater variability in proportional use for American shad, but corresponding to means reported for other out-migrants (Stich et al. 2015b). Importantly, all fish using the Stillwater Branch for downstream migration were required to pass Gilman Falls, and Stillwater and Orono dams, unlike upstream migration, which allowed for trucking.

The number of females, males, and juveniles reaching the ocean from a given PU each year was conditional on $\psi_{S T I L L D, t}$, as well as the upstream migration route and PU from which a group of downstream migrating fish originated. For each group (males, females, juveniles), the number of fish from each age class reaching the ocean was calculated using one of four statebased projection matrices based on downstream survival rates and proportional use of the Stillwater Branch by downstream migrants. After fish reached the ocean, adults (males and females) were added to the age-structured spawning pool for the next year, and juveniles were added to the age-structured recruitment pool. 


\section{Dam-passage performance standards}

The probability of upstream and downstream passage at each dam was controlled deterministically within each year of the simulation to represent management decisions, and was based on probability of passage during a given time period of either 24 or $48 \mathrm{~h}$. In this way, we were able to understand the impacts of the effectiveness and timeliness of various dam-passage performance standards on the spatial and temporal changes to abundance and age-structuring of American shad in the Penobscot River over the period of interest (50 years in this case).

For the purpose of this study, performance standards were set to be equal at all dams (i.e., catchment-scale regulation), and we assumed that a performance standard was always achieved during a given model run. Therefore, we assigned the annual probability of passage at each dam for individual fish to the performance standard at that dam in during a given simulation of 50 years. For each model run, upstream and downstream passage performance standards were sampled from a uniform categorical distribution in the set $\{0.10,0.20,0.30, \ldots, 1.00\}$. All upstream dam passage performance standards were applied over an explicit passage window of interest (time). This application can be thought of as analogous to calculation of interest rates, where daily passage probability was adjusted by time, expressed as a proportion of one day) to calculate a daily probability of passage as:

$$
\text { Daily passage probability }=(\text { passage probability })^{(1 / \text { time })}
$$

\section{We randomly drew time for each 50-year simulation from a categorical distribution with equal} sampling probabilities and values possible of 1 ( $24 \mathrm{~h}$ or $1 \mathrm{~d}$ ) and 2 (48 h or $2 \mathrm{~d}$ ) to demonstrate the influences of dam passage timeliness on population dynamics. 
634 Model outputs

A large number of outputs exist that could be tracked within a life-history based model

636 such as the one developed in this study. We chose to monitor three annual outputs from the

637 model to quantify effects of upstream and downstream dam passage on population demographics

638 in the Penobscot River catchment. These outputs were i) age-structured abundance of the

639 spawning pool in the mouth of the river, ii) abundance of the spawning pool in each PU of the

640 catchment, and iii) the proportion of repeat spawners in the spawning pool. To simplify

641 visualization of repeat spawner response to dam passage performance standards, only age-6

642 American shad were considered because this was the median age of repeat spawners in the 643 population.

644

645

Evaluating model sensitivity

A full analysis of stochastic parameters was conducted to evaluate the sensitivity of

647 model outputs to input data used for this model using a global sensitivity analysis. The purpose

648 of this analysis was two-fold. First, we were interested in which assumptions of the model were

649 most critical to predicted changes in population demographics. Second, the sensitivity analysis

650 allows us to prioritize future needs for data collection with respect to model inputs.

651 We used a one-way error analysis to identify the sensitivity of model outputs to the range

652 of individual inputs. We used generalized linear models (GLMs) to assess the effects of inputs on

653 the management objectives for management of this population, including the probability of

654 successfully reaching the State of Maine’s interim management target of 633000 fish spawning

655 in the river, and the likelihood of a sustained spawning population of American shad above 
656 Weldon Dam (MDMR 2009). Beyond being a stated management objective, the response of

657 sustained spawning populations upstream of Weldon Dam to management decisions might differ

658 substantially from spawning populations in downstream PUs by virtue of its location far

659 upstream in the catchment. Both metrics were assessed at 41-50 years following the timeline for

660 management objectives. A binomial distribution with a logit link function was used to estimate

661 the GLM associated with probability of successfully achieving the interim recovery target for

662 abundance at the mouth of the river, and a Gaussian ('normal') error distribution was used to

663 assess the sensitivity of z-standardized spawner abundance upstream of Weldon Dam to input

664 parameter values. Due to the large number of input parameters considered, sensitivity of model

665 outputs to input parameters was assessed using relative effect sizes as interpreted through the use 666 of standardized regression coefficients.

667

668 Results

669 Model sensitivity

670 Probability of achieving interim recovery target

671 Achievement of the interim recovery target of 633000 spawners in the river was most

672 sensitive to growth and size of American shad, dam passage, and natural mortality rates in 673 marine and freshwater habitats.

674 In general, the probability of achieving the interim recovery target increased with

675 increases in individual growth rate $\left(k_{s}\right)$ and theoretical maximum size $\left(L_{\infty_{s}}\right)$ for both females and

676 males (Table 3), likely because faster growth rate and greater maximum size resulted in

677 increased movement rates and access to habitat where carrying capacity was not limiting.

678 Despite this, there was a strong, negative relation between realized fork length and probability of 
679 achieving the interim recovery target (Table 3). The latter relationship was strongly suspected to 680 be representative of a proportionally larger number of smaller fishes in the population at high 681 abundance as it was counter to relations between achievement of the interim recovery target, 682 growth parameters, and passage time (Table 3). That is, we suspect that the negative relationship 683 between $L_{j}$ and probability of achieving interim recovery target was simply an artifact of 684 increased proportional abundance of small fish at higher population sizes (Table 3).

685 Dam passage was related to the probability of achieving the interim recovery target 686 through multiple mechanisms. The parameter to which population size was most sensitive was 687 downstream passage at dams (Table 3). Consistent with this, probability of achieving the 688 management objective also was inversely related to the probability of using the Stillwater 689 Branch, which contained more dams than the main-stem Penobscot River, for downstream 690 migration (Table 3). With respect to upstream passage, population abundance was sensitive to 691 both passage time, and upstream passage efficiency. Consistent with simulation results, the 692 population was more sensitive to changes in passage time (24 or $48 \mathrm{~h}$ ) than it was to changes in 693 passage efficiency (Table 3). As expected, natural mortality parameters have a clear negative effect on population 695 abundance. The probability of achieving the interim recovery target within 41-50 years was 696 strongly related to marine survival rates, and to a lesser degree was related to both the assumed 697 starting population abundance and post-spawn mortality rates for females and males (Table 3). In 698 all cases, increased survival during periods of natural attrition was positively related to the 699 probability of achieving the interim recovery target (Table 3). 
701

702

703

704

705

706

707

708

709

710

711

712

713

714

715

716

717

718

719

720

721

722

723

Number of spawners upstream of Weldon Dam

We tested the sensitivity of spawner abundance upstream of Weldon Dam as an indicator of the ability to sustain spawning populations in the upstream extent of the main-stem Penobscot River in the absence of specific numerical management targets. The sensitivity of abundance in this PU followed different trends than catchment-scale abundance. Abundance upstream of Weldon Dam was most sensitive to changes in phenology, size and movement parameters, and dam passage performance standards.

The phenological parameters to which abundance upstream of Weldon Dam was most sensitive included timing of arrival in the estuary, date of initial spawn, and stochastic changes in temperature (Table 4). In general, earlier arrival dates and initial spawning dates resulted in larger population abundances upstream of the dam, likely due to the increased window for upstream migration. Because arrival timing and spawning dates were directly linked to temperature within the simulation model, the effect of positive, stochastic changes in temperature also resulted in earlier timing of estuary arrival and earlier initial spawning dates.

By virtue of the its location far upstream in the watershed, population abundance upstream of Weldon Dam was also sensitive to a suite of parameters that related to upstream migration patterns to which catchment-wide abundance was less sensitive. These included fork length of females and males, tortuosity of movement rates, seasonal changes in migratory motivation, and realized movement rates (Table 4). Change in population abundance upstream of Weldon Dam was proportional to changes in fork lengths of females and males, as well as daily movement rates that were, in part, a function of length. Conversely, abundance of spawners in the PU was inversely related to the motivation penalty imposed, and the tortuosity of upstream movement paths (Table 4). 
725 effects on the number of spawners arriving upstream of Weldon Dam through multiple mechanisms. First, the number of spawners in the production unit decreased with the number of

727 fish that migrated up the Piscataquis River and were consequently not available for passage upstream of Weldon Dam (Table 4). Likewise, the number of spawners upstream of the dam increased with faster passage times and increased passage efficiency of dams in the catchment. As with catchment-wide abundance, the number of spawners upstream of Weldon Dam was more sensitive to downstream dam passage efficiency than upstream passage efficiency (Table 732 4), but the difference in effects was not as great as it was for catchment-wide abundance. Once critical thresholds for downstream passage performance standards were attained, abundance upstream of Weldon Dam was more sensitive to upstream passage time than efficiency, but both 735 were significant predictors (Table 4).

\section{Abundance and spatial distribution of spawners}

No passage scenario

A scenario of 'no passage' was used to establish a baseline for population abundance in the Penobscot River without fish passage, and to demonstrate the scope for change in spawner

741 abundance and proportion of repeat spawners under varying scenarios of increased upstream and 742 downstream passage. The mean predicted population size after 41-50 years under the no passage 743 scenario was about 41000 (95\% CI = 17 000-98 000; Fig. 6). The weighted mean proportion of 744 repeat spawners at ages five through seven under the no passage scenario was $0.32(0.22-0.45)$ 745 after $41-50$ years. 
No dam scenario

We used a scenario that assumed 100\% effectiveness of dam passage to estimate the potential productivity of the population in the absence of dam impacts, and to demonstrate the isolated influence of variable passage times on population abundance. Under this best-case passage scenario (upstream and downstream passage $=1.00$, time for passage $=24 \mathrm{~h}$ ), the average population abundance at the mouth of the river was predicted to increase to approximately 850000 (95\% CI: 260 000-1 900 000) fish during the 41-50 years following the implementation of performance standards (Fig. 6). The population was projected to reach this abundance after approximately 30 years. In the absence of migratory impediments (no-dam scenario), 65\% of predicted American shad abundances in the Penobscot River exceeded the interim recovery target of 633000 fish during the 41-50 year period (Fig. 6).

Changes in the abundance of spawning American shad at the mouth of the river were concurrent with changes in the spatial distribution of spawners (Fig. 7). Changes in distribution were examined with respect to both the proportion of spawners in each production unit, and the projected abundance of spawners upstream of Weldon Dam. The distribution of spawners was proportionally highest in PU 3A under both passage times (Milford Dam to West Enfield Dam; Fig. 1). The mean predicted abundance of spawners upstream of Weldon Dam in years 41-50 was about $26000(0-122$ 000) fish with a 24 h passage time.

The age distribution of repeat spawners in the population remained relatively similar between the $24 \mathrm{~h}$ and $48 \mathrm{~h}$ passage times when passage efficiency was held constant at 1.00. However, the proportion of repeat spawners in a given age class increased only marginally in the $48 \mathrm{~h}$ scenario when compared to the $24 \mathrm{~h}$ scenario (Fig. 8). Although not shown, there were some 
769

770

771

772

773

774

775

776

777

778

779

780

781

782

783

784

785

786

787

788

789

790

791

differences in the age distributions at the PU level between the 24 and 48 hours due to indirect relationship with movement speed based on fish length (i.e., older fish move faster).

\section{Variable passage efficiency}

When variable dam passage performance standards were considered at the catchmentwide scale, we observed differential effects of upstream and downstream passage on the responses of interest (population abundance at the mouth of the river, abundance upstream of Weldon Dam, and proportion of repeat spawners). We also observed interactions between the effects of upstream and downstream passage on these responses. Finally, the upstream and downstream passage rates needed to achieve interim management targets varied substantially based on passage time (24 or $48 \mathrm{~h})$.

Abundance of spawning American shad in the catchment increased with increasing upstream passage at a given downstream passage rate, but only to a certain point, after which abundance was predicted to either stabilize or even decrease with further increases in upstream passage (Fig. 9). The upstream passage rate at which this trade off occurred appeared to be dependent upon the corresponding downstream passage rate, and the tradeoff appeared to decrease in the intensity from low to high rates of downstream passage. At downstream passage rates higher than about 0.80 , abundance always increased with increases in upstream passage if a $24 \mathrm{~h}$ passage time was used. The threshold for this tradeoff occurred at lower levels of downstream passage ( 0.60) when a 48 h performance standard was used (Fig. 9).

A minimum downstream passage performance standard of about 0.90 was required for the simulated population to reach a mean abundance of 633000 fish after $41-50$ years for $24 \mathrm{~h}$ passage time, and a minimum downstream standard of 0.98 was needed under the $48 \mathrm{~h}$ upstream 
792 passage scenario (Fig. 9). Given sufficiently high downstream passage, it was possible for the 793 population to recover to the interim management objective of 633000 with upstream passage 794 rates as low as about 0.30 in $24 \mathrm{~h}$ (Fig. 9). With a $48 \mathrm{~h}$ upstream passage time, the interim 795 management objective for abundance was not achieved below upstream passage performance 796 standards of about 0.85 (Fig. 9).

The mean abundance of American shad spawning upstream of Weldon Dam responded 798 similarly to changes in upstream and downstream passage performance standards using $24 \mathrm{~h}$ and 79948 h passage times (Fig. 9). However, changes in spawner abundance upstream of Weldon Dam 800 were less sensitive to changes in downstream passage under the $48 \mathrm{~h}$ scenario than under the 24 801 h scenario (Fig. 9) as expected, because fewer fish reached this PU under the 48 h scenario. The predicted proportion of repeat spawners in the catchment increased with increasing 803 downstream passage. Probability of repeat spawning decreased with increased upstream passage 804 where corresponding downstream passage was not sufficiently high (Fig. 10). As with spawner 805 abundance, this trend indicated a tradeoff in American shad population dynamics resultant from 806 interactions between upstream and downstream passage.

807

808 Discussion

\section{Management implications}

Fishery managers charged with establishing fish passage performance standards and their

811 industry counterparts frequently enter into negotiations of regulatory standards lacking the ability

812 to quantify how passage performance standards might relate to management objectives for

813 anadromous species, which makes it difficult to accurately assess whether fishways meet criteria

814 of 'safe, timely, and effective' passage (U.S. Fish and Wildlife Service and National Oceanic and 
815 Atmospheric Administration 2000). The model developed in this study provides such a tool for 816 fishery managers who seek quantitative support for decision-making related to American shad 817 passage performance standards at regulated hydropower facilities. Although this tool was

818 developed specifically for American shad in the Penobscot River, ME, it is readily extended to 819 other populations of American shad through the inclusion of flexibility in path choice, spatial 820 arrangement of dams, and input data.

821 It is well understood that dams have the potential to adversely affect diadromous fish 822 during upstream and downstream migration. However, the degree to which passage efficiency 823 and timing of passage inhibit recovery to management goals is not well quantified. Differences 824 between species (Haro et al. 2004), in addition to site-specific considerations further complicate 825 this problem, and preclude a one-size-fits all solution to fish passage (Brownell et al. 2012).

826 Often, lack of quantitative support results in ambiguity in what constitutes 'substantial evidence' 827 (Richardson v. Perales 1971) used to determine whether or not proposed regulatory standards are 828 'arbitrary and capricious’ (CFR 1966) in negotiations (e.g., Wisconsin Power Light Company v. 829 FERC 2004) and subsequent comments (e.g., FERC 2004b). The model developed in our study, 830 with clearly developed inputs and assumptions, provides a quantitative tool based on best 831 available scientific information, and can be used to relate proposed performance standards 832 directly to management objectives for alosine species, potentially reducing much of the 833 ambiguity involved in fish passage negotiations.

835 Model application 
838

839

840

841

842

843

844

845

846

847

848

849

850

851

852

853

854

855

856

857

858

859

860

dam passage performance standards. Importantly, the interim recovery target for population abundance was only achieved under what historically have been thought of as high rates of upstream and downstream fish passage through dams. Similarly, we noted substantial changes to population abundance under different times required to pass dams, underscoring the importance of both the timeliness and effectiveness of dam passage performance standards for this species. In the absence of fish passage, this population was predicted to increase to a potential abundance of about 40000 fish on average, although maximum predictions seem to match what is expected based on previous estimates of production potential in the lower Penobscot River (MDMR 2009). These numbers seem to be reasonable given that approximately 8000 American shad passed Milford Dam during the 2016 spawning season, but the majority of tagged fish did not approach the dam that year (J. Zydlewski, unpublished data). Likewise, maximum estimates of population abundance in this system fit reasonably well compared to estimated population productivity (1.6 million spawners) in this system (MDMR 2009).

Model sensitivities indicated important aspects of life-history uncertainty and phenology that may warrant further investigation. For example, parameters related to mortality (e.g. preand post-spawn mortality, and marine survival) had substantial influences on population trends, and are biologically important drivers. Data surrounding these important sources of attrition are virtually absent from the literature. We used a wide range of values in this application, and our ability to make more precise predictions would be improved by better information. Likewise, model outputs were sensitive to changes in growth of American shad in this study. This indicates that system-specific data would be preferable to using growth information from the Connecticut River population. Those data are only now becoming more widely collected for use and will be incorporated as they become available. Limited information also exists about movement rates of 
861 American shad due to historic difficulties tagging, but studies are underway to estimate

862 migration rates and behaviors, which have the potential to replace theoretically based parameters

863 (e.g. sOptim $_{j}$, tort ${ }_{j}$, and other parameters used to parameterize $d$ Real $_{j}$ ) with empirical data.

864 Finally, the model developed here did not include variability in climate or fisheries take (harvest,

865 by-catch, discard, etc.). Such improvements would increase the overall utility of this model for

866 understanding how dam passage interplays with other influences and aspects of fisheries

867 management, and is the focus of efforts currently underway.

We made the simplifying assumption that upstream and downstream dam passage

869 performance standards were regulated at the catchment scale for modeling purposes. Singular

870 ownership of hydropower assets (National Marine Fisheries Service 2012a, 2012b), may allow

871 for catchment-wide regulation of fish passage in some hydro systems. More commonly, there

872 will be challenges within a given catchment that make such an approach inequitable,

873 unnecessary, or logistically impractical. In such cases, it may be desirable to regulate upstream

874 and downstream fish passage at individual dams to meet specific goals related to size and age

875 structure, abundance, and distribution in a catchment. Similar to previously developed tools for

876 Atlantic salmon (e.g., Nieland et al. 2015), our model provides a quantitative tool that managers

877 can use to investigate either scope of impact for a single project (i.e., effects of a single dam) in

878 isolation or with respect to contemporary conditions within a catchment in addition to

879 cumulative impacts (CFR 2014) or catchment-wide standards.

881 patterns in spatial distribution of fishes within a catchment in the absence of assumptions about

882 homing. This approach comes at the cost of computationally intensive routines that necessitate

883 increased computing time and resources. Emergent patterns in distribution could be used to 
884 inform state-based approaches in lieu of homing probabilities (sensu Nieland et al. 2015). As 885 such, the model will be useful for creating computationally efficient, simplified models for 886 alosines in the future. The ability to use such an approach previously has been limited by a lack 887 of significant evidence of population sub-structuring within natal rivers (Hasselman et al. 2010), 888 reliable information on rates of tributary fidelity in alosines (Pess et al. 2014), or even physical 889 evidence of tributary-specific homing (but see Dodson and Leggett 1973 and Hendricks et al. 890 2002). In the absence of such data, our model provides predicted patterns in distribution of 891 spawners within a catchment based on behavioral characteristics (e.g., movement speed, 892 tortuosity, and seasonal change), until better information becomes available. The model we have developed explicitly incorporates uncertainty in management 894 outcomes due to gaps in the current knowledge of diadromous species, and that allows for an 895 adaptive approach to resource management through incorporation of contemporary data as it 896 becomes available. This has helped us to identify specific components of uncertainty to which 897 the model is particularly sensitive, a stated goal for recovery efforts related to American shad 898 (ASMFC 2013). While there is uncertainty involved with many of the model inputs, the 899 influence of that uncertainty on results also is well characterized and clearly communicated using 900 tools applied in this study. Moving forward, further data collection and the development of a 901 standardized approach in coastal rivers to the assessment of alosine performance standards could 902 further reduce ambiguity and uncertainties. Thus, similar exercises will be useful for identifying 903 key knowledge gaps and prioritizing future research for other rivers and species. Despite these 904 uncertainties and sensitivities, our results demonstrate that the timelines and effectiveness of 905 upstream and downstream passage performance standards at hydropower dams can have 906 persistent effects on the recovery of alosine stocks in the northeast U.S., even when passage rates 
907 are high relative to historical passage rates for these species (ASMFC 2007, Haro and Castro-

908 Santos 2012). While exact values of input parameters and passage efficiencies necessary to 909 achieve management targets both will vary between systems, the model structure presented here 910 is well suited to address trends and sensitivities in population responses relative to resource 911 management decisions.

913 Trade-offs in upstream and downstream passage

Responses in spawner abundance to dam passage performance standards suggest that

915 delay, and ultimately passage, at hydropower dams have the potential to reduce the overall

916 number of spawning American shad in the Penobscot River, even at passage rates that

917 historically have been considered high for this species (Haro and Castro-Santos 2012). All

918 scenarios that allowed for population recovery in the Penobscot River stock of American shad

919 consisted of downstream passage rates that were greater than or equal to 0.85 . Under 48-hour

920 passage times, upstream passage efficiencies of 0.60 or greater were required to achieve interim

921 recovery targets for this population. Stock recovery in the Penobscot River population of

922 American shad is unlikely in the absence of high upstream and downstream passage rates at

923 dams; but given adequate passage, recovery to the interim recovery target is likely at the highest

924 passage rates considered in the present study (Fig. 9).

925 Previous studies indicated that the effects of changes to downstream passage on

926 American shad population abundance were minor relative to other factors, including upstream

927 passage (Kahnle and Hattala 2012); however, as the authors of that work recognize,

928 consideration of how fish passage at the catchment-scale (and not a single dam) shows that both

929 upstream and downstream fish passage can have substantial effects at the population level. In 
930 fact, we have demonstrated that if not sufficiently high, downstream passage has much greater

931 potential to impede population recovery than upstream passage dependent on catchment. This is

932 because passing multiple dams during downstream migration results in higher mortality than is

933 offset by increased reproduction in upstream habitat. This complexity is likely to be more

934 relevant when indirect and latent components of downstream fish passage at dams are

935 considered. Although indirect and latent mortality were assumed to be zero in the present study,

936 these sources of dam-related mortality are included as parameters that can be changed in the

937 present version of the model and may be of significant interest. In the absence of these sources of

938 mortality, the results of the case study may be viewed as optimistic given the sensitivity of

939 population to downstream dam passage performance standards.

Previous researchers have hypothesized that upstream passage of American shad past

941 dams could reduce in-river survival and rates of iteroparity through physiological constraints

942 associated with extended upstream migrations (Leggett et al. 2004, Kahnle and Hattala 2012).

943 Thus, it has been suggested that managers might 'do more harm than good' by passing fish

944 upstream beyond dams and into spawning habitat (Leggett et al. 2004). Alternately, increased

945 mortality and reduced iteroparity might be caused by delays at dams during downstream

946 migration, leading to undesirable population demographics at high rates of upstream passage

947 (Castro-Santos and Letcher 2010). We demonstrated a clear trade off in the response of spawner

948 abundance (Fig. 9) and the proportion of repeat spawners (Fig. 10) to changes in upstream

949 passage rates as downstream passage rate increased in our study. Congruent with the results of

950 Castro-Santos and Letcher (2010), we found that downstream passage affected rates of

951 iteroparity and spawner abundance, although we did not distinguish between mechanisms of

952 downstream mortality. For example at downstream passage rates of 0.40 , increasing upstream 
passage from 0.20 to 1.00 resulted in net reductions to population abundance because increases in productivity resulting from access to upstream habitat were insufficient to offset increases in mortality from downstream passage (Fig. 9). Importantly, passage efficiencies that achieve minimal standards for one management objective may not be conducive to achieving minimal standards for other management objectives. For example, the interim management target for catchment-wide population

959 abundance in the Penobscot River was achieved at upstream passage rates as low as 0.30 under 960 sufficiently high downstream passage efficiencies (Fig. 9). However, this upstream passage

961 efficiency resulted in a minimal abundance of spawners upstream of Weldon Dam, and much 962 higher upstream dam passage performance standards would be needed to consistently sustain 963 spawning in that production unit (Fig. 10). Likewise, at upstream passage efficiencies that 964 achieve objectives for the Weldon Dam production unit, high downstream passage rates would 965 be required to maximize the number of repeat spawners in the watershed. Therefore, both 966 upstream and downstream passage rates have important influences on American shad population 967 abundance, and those influences are inextricably linked to population dynamics and demographic 968 structuring through both space and time. Consideration of synergism between upstream and 969 downstream passage will benefit managers working to set effective dam passage performance 970 standards for American shad.

971

\section{Acknowledgements}

974 (MDMR) C. Slater (Massachusetts Division of Fish and Wildlife), B. Gahagen (Massachusetts

975 Division of Marine Fisheries), M. Bernier, J. Murphy, J. Nieland, R. McBride, S. McDermott, R. 
976 Saunders, W. McDavitt, and T. Trinko-Lake (NOAA National Marine Fisheries Service), D.

977 McCaw (Penobscot Indian Nation), M. Bailey, M. Grader, K. Sprankle, J. Sweka, and J. Warner

978 (USFWS), B. Letcher, T. Castro-Santos, and S. McCormick (USGS), and L. Will (Vermont Fish

979 and Wildlife) for valuable input on American shad management and feedback on previous

980 versions of this work, in addition to providing data and expert opinions that were instrumental to

981 this effort. Special thanks to J. Sperhac and staff at the University of Buffalo Center for

982 Computational Research, who provided access to and guidance pertaining to the use of their

983 high-performance computing cluster. This work was funded primarily by the Habitat

984 Conservation Division and the Northeast Fisheries Science Center of the NOAA's National

985 Marine Fisheries Service. In-kind support was provided by the U.S. Geological Survey Maine

986 Cooperative Fish and Wildlife Research Unit. All data generated or analyzed during this study

987 are included in the main text of this publication. All computer code is open-source, and is made

988 available through the 'shadia’ package for R that can be installed from GitHub:

989 https://github.com/danStich/shadia. Mention of trade names or commercial products does not 990 imply endorsement by the U.S. Government.

991

992 References

993 Agostinho, C.S., Pereira, C.R., Oliveira, R.J. de, Freitas, I.S., and Marques, E.E. 2007.

994 Movements through a fish ladder: temporal patterns and motivations to move upstream.

995 Neotropical Ichthyol. 5(2): 161-167. doi: 10.1590/S1679-62252007000200010.

996 Atlantic States Marine Fisheries Commission (ASMFC). 2007. American shad stock assessment

997 report for peer review (Supplement), Volume II. Stock Assessment Report, ASMFC,

$998 \quad$ Arlington, VA. 
Atlantic States Marine Fisheries Commission (ASMFC). 2010. Amendment 3 to the interstate fishery management plan for shad and river herring (American shad management). ASMFC, Arlington, VA. Available from http://www.asmfc.org/uploads/file/Amendment3_FINALshad.pdf [accessed 18 May 2015].

Atlantic States Marine Fisheries Commission (ASMFC). 2013. Research priorities and recommendations to support interjurisdictional fisheries management: American shad/river herring. Special Report, ASMFC, Arlington, VA. Available from http://www.asmfc.org/uploads/file/ResearchPriorities_AMShad_RHerring_June2013.pdf.

Bailey, M.M., Isely, J.J., and Bridges, W.C. 2004. Movement and Population Size of American Shad near a Low-Head Lock and Dam. Trans. Am. Fish. Soc. 133(2): 300-308. doi: 10.1577/03-025.

Bailey, M.M., and Zydlewski, J.D. 2013. To Stock or Not to Stock? Assessing the Restoration Potential of a Remnant American Shad Spawning Run with Hatchery Supplementation. North Am. J. Fish. Manag. 33(3): 459-467. doi: 10.1080/02755947.2013.763874.

von Bertalanffy, L. 1938. A quantitative growth theory of organic growth (inquiries on growth laws II). Hum. Biol. 10(2): 181-213.

Bethoney, N.D., Stokesbury, K.D.E., Schondelmeier, B.P., Hoffman, W.S., and Armstrong, M.P. 2014. Characterization of river herring bycatch in the Northwest Atlantic midwater trawl fisheries. North Am. J. Fish. Manag. 34(4): 828-838. doi: 10.1080/02755947.2014.920736.

Brett, J.R. 1962. Some considerations in the study of respiratory metabolism in fish, particularly salmon. J. Fish. Res. Bd. Canada 19(6):1025-1038. doi: https://doi.org/10.1139/f62-067. 
1022 Brownell, P., Haro, A., McDermott, S., Blott, A., and Rhode, F. 2012. Diadromous fish passage:

1023

1024

1025

1026

1027

1028

1029

1030

1031

1032

1033

1034

1035

1036

1037

1038

1039

1040

1041

1042

a primer on technology, planning and design for the Atlantic and Gulf coasts. National

Marine Fisheries Service and the US Geological Survey Conte Anadromous Fish

Research Center. Available from

https://www.salmonrecovery.gov/Files/APR/Section\%202\%20Literature\%20Cited/Trum bo\%20et\%20al\%202013b_Improving-hydroturbine-pressures-enhance-salmon-passagesurvival.pdf.

Brown, J.J., Limburg, K.E., Waldman, J.R., Stephenson, K., Glenn, E.P., Juanes, F., and Jordaan, A. 2013. Fish and hydropower on the U.S. Atlantic coast: failed fisheries policies from half-way technologies. Conserv. Lett. 6(4): 280-286. doi: 10.1111/conl.12000.

Budy, P., Thiede, G.P., Bouwes, N., Petrosky, C.E., and Schaller, H. 2002. Evidence linking delayed mortality of Snake River salmon to their earlier hydrosystem experience. North Am. J. Fish. Manag. 22(1): 35-51. doi: 10.1577/15488675(2002)022<0035:ELDMOS>2.0.CO;2.

Castro-Santos, T., and Letcher, B.H. 2010. Modeling migratory energetics of Connecticut River American shad (Alosa sapidissima): implications for the conservation of an iteroparous anadromous fish. Can. J. Fish. Aquat. Sci. 67(5): 806-830. doi: 10.1139/F10-026.

CFR. 1966. Scope of review. Code of Federal Regulations Title 5, Pt. 1.706.

CFR. 2014. Cumulative impact. Title 40, Pt 1508.7.

Day, L.R. 2006. Restoring native fisheries to Maine’s largest watershed: the Penobscot River Restoration Project. J. Contemp. Water Res. Educ. 134(1): 29-33. 
1043 1044 1045 1046 1047 1048 1049 1050 1051 1052 1053 1054 1055 1056 1057 1058 1059 1060 1061 1062 1063 1064 1065

Dodson, J.J., and W. Leggett. 1973. Behavior of adult American shad (Alosa sapidissima) homing to the Connecticut River from Long Island Sound. J. Fish. Res. Board. Can. 30:1847-1860.

Doucett, R.R., R.K. Booth, G. Power, and R.S. McKinley. 1999. Effects of the spawning migration on the nutritional status of anadromous Atlantic salmon (Salmo salar): insights from stable-isotope analysis. Can. J. Fish. Aquat. Sci. 56(11):2172-2180.

Duffy, W.J., McBride, R.S., Hendricks, M.L., and Oliveira, K. 2012. Otolith age validation and growth estimation from oxytetracycline-marked and recaptured American shad. Trans. Am. Fish. Soc. 141(6): 1664-1671. doi: 10.1080/00028487.2012.720631.

Eddelbuettel, D. and R. Francois. 2011. Rcpp: seamless R and C++ integration. J. Stat. Softw. 40(8):1-18. URL http://www.jstatsoft.org/v40/i08/.

Federal Energy and Regulatory Commission [FERC]. 2004a. Submittal of the Lower Penobscot River Basin comprehensive settlement accord with explanatory statement for FERC project numbers 2403, 2534, 2666, 2710, 2712, 2721, and 10981. United States Department of Energy, Washington, DC. Available from http://elibrary.ferc.gov/idmws/common/OpenNat.asp?fileID=10188480 [accessed 17 June 2015].

Federal Energy and Regulatory Commission [FERC]. 2004b. Order denying rehearing for FERC project 2016-086. Washingto, D. C. Available from http://www.ferc.gov/whatsnew/comm-meet/111804/H-3.pdf.

Federal Energy and Regulatory Commission [FERC]. 2009. Draft environmental assessment, application for surrender of license for FERC project numbers 2403-056, 2312-019 and 2721-20. United States Department of Energy, Washington, DC. Available from 
http://www.penobscotriver.org/assets/FERC_Environmental_Assessment_-_Draft_8-409.pdf [accessed 18 May 2015].

Foster, N.W., and Atkins, G.C. 1869. Second report of the commissioners of fisheries of the state of Maine 1868. Owen and Nash.

Gorsky, D., Trial, J., Zydlewski, J., and McCleave, J. 2009. The effects of smolt stocking strategies on migratory path selection of adult Atlantic salmon in the Penobscot River, Maine. North Am. J. Fish. Manag. 29(4): 949-957. doi: 10.1577/M08-068.1.

Grote, A.B., Bailey, M.M., and Zydlewski, J.D. 2014a. Movements and demography of spawning American shad in the Penobscot River, Maine, prior to dam removal. Trans. Am. Fish. Soc. 143(2): 552-563. doi: 10.1080/00028487.2013.864705.

Grote, A.B., Bailey, M.M., Zydlewski, J.D., Hightower, J.E., and Jech, J.M. 2014b. Multibeam sonar (DIDSON) assessment of American shad ( Alosa sapidissima ) approaching a hydroelectric dam. Can. J. Fish. Aquat. Sci. 71(4): 545-558. doi: 10.1139/cjfas-20130308.

Haro, A., and Castro-Santos, T. 2012. Passage of American shad: paradigms and realities. Mar. Coast. Fish. 4(1): 252-261. doi: 10.1080/19425120.2012.675975.

Haro, A., Castro-Santos, T., Noreika, J., and Odeh, M. 2004. Swimming performance of upstream migrant fishes in open-channel flow: a new approach to predicting passage through velocity barriers. Can J Fish Aquat Sci. 61(9): 1590-1601. doi: 10.1139/f04-093.

Harris, J.E., and Hightower, J.E. 2012. Demographic population model for American shad: will access to additional habitat upstream of dams increase population sizes? Mar. Coast. Fish. 4(1): 262-283. doi: 10.1080/19425120.2012.675969. 
1088

1089

1090

1091

1092

1093

1094

1095

1096

1097

1098

1099

1100

1101

1102

1103

1104

1105

1106

1107

1108

1109

1110

Hasselman, D.J., Bradford, R.G., and Bentzen, P. 2010. Taking stock: defining populations of American shad (Alosa sapidissima) in Canada using neutral genetic markers. Can. J. Fish. Aquat. Sci. 67(6): 1021-1039. doi: 10.1139/F10-031.

Hasselman, D.J., and Limburg, K.E. 2012. Alosine restoration in the 21st Century: Challenging the Status Quo. Mar. Coast. Fish. 4(1): 174-187. doi: 10.1080/19425120.2012.675968.

Hendricks, M.L., Hoopes, R.L., Arnold, D.A., and Kaufmann, M.L. 2002. Homing of hatcheryreared American shad to the Lehigh River, a Tributary to the Delaware River. North Am. J. Fish. Manag. 22(1): 243-248. doi: 10.1577/15488675(2002)022<0243:HOHRAS>2.0.CO;2.

Hijmans, R.J. 2016. Geosphere: spherical trigonometry. R package version 1.5-5.

Hoenig, J.M. 1983. Empirical use of longevity data to estimate mortality rates. Fish. Bull. 82(4): 898-903.

Hyle, A.R., McBride, R.S., and Olney, J.E. 2014. Determinate versus indeterminate fecundity in American shad, an anadromous clupeid. Trans. Am. Fish. Soc. 143(3): 618-633. doi: 10.1080/00028487.2013.862178.

Kahnle, A., and Hattala, K. 2012. Relative sensitivity of New England American shad to fishing, discard mortality, and dam passage failure or mortality. Mar. Coast. Fish. 4(1): 294-301. doi: 10.1080/19425120.2012.675981.

Kynard, B., and J. O'Leary. 1993. Evaluation of a bypass system for spent American shad at Holyoke Dam, Massachusetts. N. Am. J. Fish. Manage. 13(4):782-789.

Leggett, W.C. 1977. Density dependence, density independence, and recruitment in the American shad (Alosa sapidissima) population of the Connecticut River. Available from http://inis.iaea.org/Search/search.aspx?orig_q=RN:9394908 [accessed 15 June 2015]. 
1111 Leggett, W.C., Savoy, T.F., and Tomichek, C.A. 2004. The impact of enhancement initiatives on the structure and dynamics of the Connecticut River population of American shad. In The Connecticut River Ecological Study (1965-1973) revisited: ecology of the Lower Connecticut River 1973-2003. Edited by P.M. Jackobson, D.A. Dixon, W.C. Leggett, B.C. Marcy, and R.R. Massengill. pp. 391-405.

Limburg, K.E., and Waldman, J.R. 2009. Dramatic declines in North Atlantic diadromous fishes. BioScience 59(11): 955-965. doi: 10.1525/bio.2009.59.11.7.

Limburg, K., Hattala, K., and Kahnle, A. 2003. American shad in its native range. Biodivers. Status Conserv. Worlds Shads: 125-140.

Maine Department of Marine Resources (MDMR). 2009. Operational plan for the restoration of diadromous fishes to the Penobscot River. Final Report, MDMR, Maine Department of Inland Fish and Wildlife, Augusta, ME. Available from http://maine.gov/dmr/searunfish/reports/Penobscot_Operational_Plan_final_2009.pdf [accessed 18 May 2017].

Nadeau, P.S. 2007. Parental contributions to the early life history traits of juvenile sockeye salmon (Oncorhynchus nerka): the roles of spawner identity and migratory experience. M.S. thesis, University of British Columbia, Vancouver, British Columbia.

National Marine Fisheries Service. 2012a. Endangered species act biological opinion for Federal Energy Regulatory Commission projects 2403, and 2721. National Marine Fisheries Service, Silver Spring, MD. Available from http://www.greateratlantic.fisheries.noaa.gov/protected/section7/bo/actbiops/prrp_opinio n_2012.pdf [accessed 13 July 2017]. 
1133 National Marine Fisheries Service. 2012b. Endangered species act biological opinion for Federal

1134

1135

1136

1137

1138

1139

1140

1141

1142

1143

1144

1145

1146

1147

1148

1149

1150

1151

1152

1153

1154

Energy Regulatory Commission projects 2710, 2712, 2354, 2600, and 2666. National Marine Fisheries Service, Silver Spring, MD. Available from http://www.greateratlantic.fisheries.noaa.gov/prot_res/section7/FERC-signedBOs/BlackBearHydroBO.pdf [accessed 7 September 2015].

Naughton, G.P., C.C. Caudill, M.L. Keefer, T.C. Bjornn, C.A. Peery, and L. Stuehrenberg. 2005. Late-season mortality during migration of radio-tagged adult sockeye salmon (Oncorhynchus nerka) in the Columbia River. Can. J. Fish. Aquat. Sci. 62(1):30-47. doi: https://doi.org/10.1139/f04-147.

Nieland, J.L., Sheehan, T.F., and Saunders, R. 2015. Assessing demographic effects of dams on diadromous fish: a case study for Atlantic salmon in the Penobscot River, Maine. ICES J. Mar. Sci. doi: 10.1093/icesjms/fsv083.

O'Leary, J.A., and B. Kynard. 1986. Behavior, length, and sex ratio of seaward-migrating juvenile American shad and blueback herring in the Connecticut River. Trans, Am. Fish. Soc. 115(4):529-536. doi: http://dx.doi.org/10.1577/15488659(1986)115<529:BLASRO>2.0.CO;2.

Olney, J.E., and Hoenig, J.M. 2001. Managing a fishery under moratorium: assessment opportunities for Virginia’s stocks of American shad. Fisheries 26(2): 6-12. doi: 10.1577/1548-8446(2001)026<0006:MAFUMA>2.0.CO;2.

Olney, J.E., Latour, R.J., Watkins, B.E., and Clarke, D.G. 2006. Migratory behavior of American Shad in the York River, Virginia, with implications for estimating in-river exploitation from tag recovery data. Trans. Am. Fish. Soc. 135(4): 889-896. doi: 10.1577/T05-101.1. 
1155

1156

1157

1158

1159

1160

1161

1162

1163

1164

1165

1166

1167

1168

1169

1170

1171

1172

1173

1174

1175

1176

Pess, G.R., Quinn, T.P., Gephard, S.R., and Saunders, R. 2014. Re-colonization of Atlantic and Pacific rivers by anadromous fishes: linkages between life history and the benefits of barrier removal. Rev. Fish Biol. Fish. 24(3): 881-900. doi: 10.1007/s11160-013-9339-1.

Petersen, J.H., Hinrichsen, R.A., Gadomski, D.M., Feil, D.H., and Rondorf, D.W. 2003.

American shad in the Columbia River. In Biodiversity, status, and conservation of the world’s shads. American Fisheries Society, Symposium 35. Edited by K.E. Limburg and J.R. Waldman. American Fisheries Society, Bethesda, MD. pp. 141-155.

Powell, A.M., and Xu, J. 2011. Abrupt climate regime shifts, their potential forcing and fisheries impacts. Atmospheric Clim. Sci. 01(02): 33-47. doi: 10.4236/acs.2011.12004.

Raabe, J.K., and Hightower, J.E. 2014. American Shad migratory behavior, weight loss, survival, and abundance in a North Carolina River following dam removals. Trans. Am. Fish. Soc. 143(3): 673-688. doi: 10.1080/00028487.2014.882410.

R Core Team. 2016. R: a language and environment for statistical computing. Available from http://www.R-project.org/.

Rand, P.S., and S.G. Hinch. 1998. Swim speeds and energy use of upriver-migrating sockeye salmon (Oncorhynchus nerka): simulating metabolic power and assessing risk of energy depletion. Can. J. Fish. Aquat. Sci. 55(8):1832-1841. doi: https://doi.org/10.1139/f98068.

Richardson v. Perales. 1971. 402 2d US 389.

Rulifson, R.A. 1994. Status of anadromous Alosa along the east coast of north American. In Anadromous alosa symposium: proceedings of a symposium held at the seventh annual meeting of the Tidewater Chapter in Virginia Beach, Virginia, 14-15 January 1993. 
1177 1178

1179 1180 1181 1182 1183

1184 1185 1186

Edited by J.E. Cooper, R.T. Eades, R.J. Klauda, and J.G. Loesch. American Fisheries Society, Bethesda, MD. pp. 134-158.

Ryberg, K.R., and Vecchia, A.V. 2012. waterData: An R package for retrieval, analysis, and anomaly calculation of daily hydrologic time series data. Available from http://cran.rproject.org/web/packages/waterData/index.html [accessed 11 June 2015].

Savoy, T.F., Crecco, V.A., and Marcy, Jr., B.C. 2004. American shad early life-history and recruitment in the Connecticut River: a 40-year summary. In The Connecticut River ecological study (1965-1973) revisited: ecology of the lowe Connecticut River. Edited by P.M. Jacobson, D.A. Dixon, W.C. Leggett, B.C. Marcy, Jr., and R.R. Massengill. American Fisheries Society. pp. 407-417. Available from http://psb.vermont.gov/sites/psb/files/docket/7862relicense4/Exhibit\%20EN-LWB-1.pdf [accessed 15 June 2015].

Schaller, H.A., Petrosky, C.E., and Tinus, E.S. 2014. Evaluating river management during seaward migration to recover Columbia River stream-type Chinook salmon considering the variation in marine conditions. Can. J. Fish. Aquat. Sci. 71(2): 259-271. doi: 10.1139/cjfas-2013-0226.

Stevenson, C.H. 1899. The shad fisheries of the Atlantic coast of the United States. In U.S. Commission of Fish and Fisheries, Part XXIV. Report of the Commissioner for the year ending June 30, 1898. U.S. Government Printing Office. pp. 101-269.

Stich, D.S., Bailey, M.M., Holbrook, C.M., Kinnison, M.T., Zydlewski, J.D., and Bradford, M. 2015b. Catchment-wide survival of wild- and hatchery-reared Atlantic salmon smolts in a changing system. Can. J. Fish. Aquat. Sci.: 1-14. doi: 10.1139/cjfas-2014-0573. 
1199 Stich, D.S., Bailey, M.M., and Zydlewski, J.D. 2014. Survival of Atlantic salmon Salmo salar

1200

1201

1202

1203

1204

1205

1206

1207

1208

1209

1210

1211

1212

1213

1214

1215

1216

1217

1218

1219

1220

1221 smolts through a hydropower complex: smolt survival through a hydropower complex. J. Fish Biol. 85(4): 1074-1096. doi: 10.1111/jfb.12483.

Stich, D.S., Zydlewski, G.B., Kocik, J.F., and Zydlewski, J.D. 2015a. Linking behavior, physiology, and survival of Atlantic salmon smolts during estuary migration. Mar. Coast. Fish. 7(1): 68-86. doi: 10.1080/19425120.2015.1007185.

Stier, D.J., and J.H. Crance. 1985. Habitat suitability index models and instream flow suitability curves: American shad. United States Fish and Wildlife Service (USFWS) Biological Report 82. USFWS, Washington, D.C. Available from https://www.nwrc.usgs.gov/wdb/pub/hsi/hsi-088.pdf [accessed 13 July 2017].

Susquehanna River Anadromous Fish Restoration Cooperative (SRAFRC). 2010. Migratory fish management and restoration plan for the Susquehanna River Basin,

Trinko Lake, T.R.T., Ravana, K.R., and Saunders, R. 2012. Evaluating Changes in Diadromous Species Distributions and Habitat Accessibility following the Penobscot River Restoration Project. Mar. Coast. Fish. 4(1): 284-293. doi: 10.1080/19425120.2012.675971.

U.S. Fish and Wildlife Service, and National Oceanic and Atmospheric Administration. 2000. Notice of Proposed Interagency Policy on the Prescription of Fishways Under Section 18 of the Federal Power Act. Fed. Regist. 65(247): 80898-80904.

Venables, W.N., and Ripley, B.D. 2002. MASS: Modern applied statistics with S. Available from http://www.stats.ox.ac.uk/pub/MASS4 [accessed 19 March 2017].

Wisconsin Power Light Company v. Federal Energy Regulatory Commission. 2004. 363 3d 453. Available from http://openjurist.org/363/f3d/453 [accessed 19 March 2017]. 
1222 Wootton, R.J. 1990. Ecology of Teleost Fishes. Chapman and Hall, London.

1223 Zeileis, A., Grothendieck, G. 2005. zoo: S3 infrastructure for regular and irregular time series. J.

1224 Stat. Softw. 14(6): 1-27. doi:10.18637/jss.v014.i06

1225

1226

1227

1228

1229

1230

1231

1232

1233

1234

1235

1236

1237

1238

1239

1240

1241

1242

1243

1244 


\section{Tables}

1246

1247

1248

1249

Table 1. Adult production potential for American shad production units in each migration route used in for modeling American shad in the Penobscot River, Maine, derived from production potentials calculated by Maine Department of Marine Resources (2009).

\begin{tabular}{llr}
\hline Production unit & Description & Production potential \\
\hline 1A & Head of tide to Orono & 57212 \\
2A & Orono to Milford & 49207 \\
1C & Orono to Stillwater & 1000 \\
2C & Stillwater to Gilman Falls & 10000 \\
3A & Milford to Confluence & 439591 \\
4A & West Enfield to Weldon & 538940 \\
5A & Upstream of Weldon & 230109 \\
1B & Howland to Browns Mill & 206487 \\
2B & Browns Mill to Moosehead & 1053 \\
3B & Moosehead to Guilford & 22591 \\
4B & Upstream of Guilford & 14922 \\
\hline
\end{tabular}


Table 2. Parameters used as input for modeling American shad in the Penobscot River, Maine. Note that user-defined parameters for upstream passage efficiencies, downstream passage efficiencies, and passage timing (time) are not shown here. Likewise, parameters that were derived directly from those presented here, but used in sensitivity analysis (e.g., dMax, $d$ Real) may not be shown.

\begin{tabular}{|c|c|c|c|}
\hline Parameter & Description & Distribution or value & Reference \\
\hline$N_{i=1}$ & Starting total number of age-1 fish in the population & $\mathrm{P}(\lambda=10000)$ & MDMR 2009 \\
\hline$S_{M, i, t}$ & Marine survival & $\operatorname{Beta}(a=12, b=8)$ & ASMFC 2007 \\
\hline$R F_{i}$ & Age-specific probabilities of recruitment to first spawn & $\operatorname{Bernoulli}(p=$ age-specific $)$ & Bailey and Zydlewski 2013 \\
\hline pFemale $_{t}$ & Proportion of females in spawning population & $\operatorname{Beta}(a=100, b=100)$ & Bailey and Zydlewski 2013 \\
\hline$d$ Temp $_{t}$ & Mean daily temperatures & MVN(year, day, temperature) & USGS Gage 01036390 \\
\hline$A T U_{d}, j$ & ATU experienced by each fish on each day & Derived from $d T e m p_{t}$ & USGS Gage 01036390 \\
\hline tStoch, $t$ & Stochastic change for prediction from commercial catch regression & $\mathrm{U}(-1.96,1.96)$ & Stochastic parameter- no data \\
\hline tArrival $_{j}$ & Arrival ATU & Derived & CTDEEP, unpublished data \\
\hline dArrival $_{j}$ & Arrival date corresponding to arrival ATU & Derived & CTDEEP, unpublished data \\
\hline$t_{S p a w n}$ INTITIAL, $j$ & Initial spawning temperature & $\mathrm{N}(\mu=150, \sigma=15)$ & Expert opinion \\
\hline$t_{S p a w n}$ TERMINAL,j & Terminal spawning temperature & $\mathrm{N}(\mu=500, \sigma=15)$ & Expert opinion \\
\hline$d S p a w n_{\text {INTITIAL, } j}$ & Initial spawning date & Derived annually & Based on simulated temperature \\
\hline dSpawn TERMINAL, $j$ & Terminal spawning date & Derived annually & Based on simulated temperature \\
\hline$L_{\infty_{S}}$ & Maximum length in von Bertalanffy growth model & Derived annually & CTDEEP, unpublished \\
\hline$k_{s}$ & Brody growth coefficient in von Bertalanffy growth model & Derived annually & CTDEEP, unpublished \\
\hline$t_{0_{s}}$ & Intercept in von Bertalanffy growth model & Derived annually & CTDEEP, unpublished \\
\hline$B F_{V, j}$ & Batch fecundity for individual virgin spawners & $\mathrm{NB}(\mu=20000, \theta=10)$ & Hyle et al. 2014 \\
\hline$B F_{R, j}$ & Batch fecundity for individual repeat spawners & $\mathrm{NB}(\mu=30000, \theta=10)$ & Hyle et al. 2014 \\
\hline$S I_{j}$ & Spawning interval & $\mathrm{N}(\mu=2.49, \sigma=0.27)$ & Hyle et al. 2014 \\
\hline$I p R$ & Initial age-specific probabilities of repeat spawning & $\operatorname{Bernoulli}(p=$ age-specific $)$ & ASMFC 2007 \\
\hline$\psi_{\text {STILLUP, } t}$ & Probability of using Stillwater Branch during upstream migration & $\mathrm{U}(0.10-0.40)$ & Gorsky et al. 2009 \\
\hline$\psi_{P I S C U P,} t$ & Probability of using Piscataquis River during upstream migration & $\mathrm{U}(0.30-0.50)$ & Gorsky et al. 2009 \\
\hline sOptim $_{j}$ & Optimal ground speed & $\mathrm{U}(0.7-1.7)$ & Castro-Santos and Letcher 2010 \\
\hline tort $_{j}$ & Tortuosity of swimming path & $\mathrm{U}(0.2-1.0)$ & Castro-Santos and Letcher 2010 \\
\hline motivation $_{j, d}$ & Seasonal movement penalty & Derived annually & USFWS, unpublished \\
\hline$\psi_{\text {STILLD, } t}$ & Probability of using Stillwater Branch for downstream migration & $\operatorname{Beta}(a=50, b=300)$ & Stich et al. 2015b \\
\hline$S_{P R E, t, s}$ & Pre-spawning survival (sex-specific) & $\operatorname{Beta}(a=1000, b=50)$ & Expert opinion \\
\hline$S_{P O S T, t, s}$ & Post-spawning survival (sex-specific) & $\operatorname{Beta}(a=200, b=50)$ & Raabe and Hightower 2014 \\
\hline$S_{J U V, t}$ & Egg to out migrant survival & $\mathrm{U}(0.00056-0.00083)$ & Legget 1977 \\
\hline$M_{I}$ & Proportional reduction in survival per dam for indirect mortality & $\mathrm{U}(0.90,1.00)$ & Budy et al. 2002; Stich et al. 2015b \\
\hline$M_{L}$ & Proportional reduction in survival per dam for latent mortality & $\mathrm{U}(0.90,1.00)$ & Budy et al. 2002; Stich et al. 2015a \\
\hline
\end{tabular}


1256

1257

1258

1259

1260

1261

1262

Table 3. Results of the one-way sensitivity analysis used to test sensitivity of achieving interim recovery target (633 000 spawners) to the range model inputs showing parameter, standardized regression coefficients (Mean), and standard errors (S.E.) on the logit scale. Notation is defined as in text and Table 2. Note: not all input parameters shown in Table 2 were assessed in sensitivity analyses, either for lack of tractable method of testing sensitivity (e.g. IpR), to reduce parameter redundancy in derived quantities in favor of inputs (e.g., $S I_{j}, R T_{j}$, and $B F_{j}$ instead of $R A F_{j}$ ), or because they were held constant for application to the Penobscot River (e.g., $M_{I}, M_{L}$ ).

\begin{tabular}{|c|c|c|}
\hline Parameter & Mean & S.E. \\
\hline$L_{j}$ (female) & -7.169193347 & 0.444715499 \\
\hline$L_{j}$ (male) & -7.165133148 & 0.420592318 \\
\hline Downstream dam passage efficiency & 3.576196219 & 0.019432129 \\
\hline$S_{M, i, t}$ & 0.698394967 & 0.007476331 \\
\hline time & -0.669643333 & 0.007267749 \\
\hline Upstream dam passage efficiency & 0.652657242 & 0.007319925 \\
\hline$L_{\infty M A L E}$ & 0.276496793 & 0.024646579 \\
\hline$L_{\infty F E M A L E}$ & 0.264555744 & 0.032712680 \\
\hline$k_{F E M A L E}$ & 0.227162237 & 0.049225669 \\
\hline$k_{M A L E}$ & 0.171897581 & 0.023146296 \\
\hline dSpawn $_{\text {INTITIAL, } j}$ & -0.084066221 & 0.281790472 \\
\hline dSpawn ${ }_{\text {TERMINAL,j }}$ & 0.083094141 & 0.224850488 \\
\hline$N_{i=1}$ & 0.079987359 & 0.005987814 \\
\hline dReal $_{j}$ & -0.069974814 & 0.037545791 \\
\hline$d M a x_{j}$ & 0.069092713 & 0.157804798 \\
\hline tort $_{j}$ & 0.059499582 & 0.031742330 \\
\hline$\psi_{\text {STILLD, } t}$ & -0.048243504 & 0.006879981 \\
\hline$S_{P O S T, t, s}=$ MALE & 0.038660923 & 0.006867843 \\
\hline$S_{P O S T, t, s}=$ FEMALE & 0.031089098 & 0.006843283 \\
\hline sOptim $_{j}$ & -0.028333415 & 0.152790528 \\
\hline tStoch & -0.026776894 & 0.012648591 \\
\hline$B F_{V, j} B F_{R, j}$ & 0.026456718 & 0.048631231 \\
\hline$R T_{j}$ & -0.023387573 & 0.064146763 \\
\hline dArrival $_{j}$ (male) & -0.022220807 & 0.048336565 \\
\hline dArrival $_{j}$ (female) & 0.019770956 & 0.058795249 \\
\hline motivation $_{j, d}$ & 0.017703110 & 0.012701736 \\
\hline$\psi_{\text {STILLUP, } t}$ & -0.010913269 & 0.006903842 \\
\hline$S_{P R E, t, s}=$ FEMALE & -0.008540375 & 0.006825587 \\
\hline$S I_{j}$ & 0.006846521 & 0.015513215 \\
\hline$t S p a w n_{\text {INTITIAL, } j}$ & 0.006188369 & 0.008655086 \\
\hline$S_{P R E, t, s}=$ FEMALE & -0.005995932 & 0.006856433 \\
\hline pFemale $_{t}$ & 0.005489176 & 0.007306242 \\
\hline$\psi_{P I S C U P, t}$ & 0.004360307 & 0.006855703 \\
\hline$t_{S p a w n}$ TERMINAL,j & 0.002494996 & 0.008250358 \\
\hline$S_{J U V, t}$ & 0.002191740 & 0.006845216 \\
\hline
\end{tabular}


1266

1267

1268

1269

1270

1271

1272

Table 4. Results of the one-way sensitivity analysis used to test sensitivity of spawning population upstream of Weldon Dam to the range model inputs showing parameter, standardized regression coefficients (Mean), and standard errors (S.E.). Note: not all input parameters shown in Table 2 were assessed in sensitivity analyses, either for lack of tractable method of testing sensitivity (e.g. $I p R$ ), to reduce parameter redundancy in derived quantities in favor of inputs (e.g., $S I_{j}, R T_{j}$, and $B F_{j}$ instead of $R A F_{j}$ ), or because they were held constant for application to the Penobscot River (e.g., $M_{I}, M_{L}$ ).

\begin{tabular}{|c|c|c|}
\hline Parameter & Mean & S.E. \\
\hline dSpawn $_{\text {INITIALj }}$ & 0.356969978 & 0.050476182 \\
\hline dArrival $_{j}$ (female) & -0.259498378 & 0.010329833 \\
\hline$L_{j}$ (male) & 0.251702980 & 0.069039450 \\
\hline dArrival $_{j}$ (male) & -0.249560752 & 0.008660360 \\
\hline$L_{j}$ (female) & 0.206105899 & 0.073561410 \\
\hline Downstream dam passage efficiency & 0.203141041 & 0.001403832 \\
\hline time & -0.171806419 & 0.001350061 \\
\hline Upstream passage efficiency & 0.159996529 & 0.001349858 \\
\hline$d S p a w n_{\text {TERMINALj }}$ & 0.126133287 & 0.040396812 \\
\hline dReal $_{j}$ & 0.119319364 & 0.006634726 \\
\hline tStoch & 0.089194725 & 0.002363211 \\
\hline motivation $_{j, d}$ & -0.089044807 & 0.002460006 \\
\hline tort $_{j}$ & -0.063184828 & 0.005609783 \\
\hline$d M a x_{j}$ & -0.033205439 & 0.027734137 \\
\hline$N_{i=1}$ & 0.024010326 & 0.001337094 \\
\hline$B F_{V, j}, B F_{R, j}$ & 0.017647192 & 0.008931618 \\
\hline$R T_{j}$ & 0.015619783 & 0.011769582 \\
\hline$\psi_{P I S C U P, t}$ & -0.010767754 & 0.001327437 \\
\hline$L_{\infty_{M A L E}}$ & -0.008741993 & 0.00459768 \\
\hline$k_{M A L E}$ & -0.005579567 & 0.004419165 \\
\hline$S_{P O S T, t, s}=F E M A L E$ & 0.004038625 & 0.001327556 \\
\hline$t_{S p a w n_{\text {INITIAL, } j}}$ & 0.003933966 & 0.001525883 \\
\hline$S I_{j}$ & 0.003546897 & 0.002755401 \\
\hline$t_{S p a w n_{\text {TERMINAL,j }}}$ & -0.003450530 & 0.001459058 \\
\hline sOptim $_{j}$ & -0.003147970 & 0.026855943 \\
\hline$\psi_{\text {STILLD, } t}$ & -0.003013612 & 0.001327047 \\
\hline$S_{P O S T, t, s}=$ MALE & 0.002285055 & 0.001327391 \\
\hline$k_{F E M A L E}$ & 0.001843472 & 0.009528543 \\
\hline$S_{P R E, t, s}=$ FEMALE & 0.001084105 & 0.001327561 \\
\hline$S_{P R E, t, s}=$ MALE & 0.001065686 & 0.001327318 \\
\hline pFemale $_{t}$ & 0.000868768 & 0.001401131 \\
\hline$S_{J U V, t}$ & -0.000619164 & 0.001327530 \\
\hline$\psi_{\text {STILLUP, } t}$ & -0.000436834 & 0.001327706 \\
\hline$L_{\infty \text { FEMALE }}$ & -0.000281815 & 0.006226972 \\
\hline$S_{M, i, t}$ & 0.000085300 & 0.001327524 \\
\hline
\end{tabular}




\section{Figure captions}

1276 Fig. 1. Map showing the location of the Penobscot River in Maine, USA (small inset), potential

1277

1278

1280

1281

1282

1283

1284

1285

1286

1287

1288

1289

1290

1291

1292

1293

1294

1295

1296 spawning range of American shad following implementation of the Penobscot River Restoration Project (PRRP), and locations of dams. Dams are shown as black bars across the river, and numbers in parentheses indicate the river kilometer (rkm) of each dam. Production units (PUs, delineated by dams) are labeled for each reach of the river from downstream to upstream, corresponding to habitat delineations in Table 1. Digital map sources include ESRI Canada (provinces and territories of Canada), United States Census Bureau (USA cartographic boundary shapefiles), and the United States Geological Survey (National Hydrography Dataset [NHD]).

Fig. 2. Schematic representation of American shad production units (PUs) within the Penobscot River catchment provided in Table 1, and migratory routes for upstream and downstream migration (i, ii, iii, and iv) based on the locations of dams in the river. Circles representing production units are proportional to estimated production potential (MDMR 2009) on a log-10 scale.

Fig. 3. Life-history diagram for American Shad showing schematic representation of modeling approach. Solid white boxes are discrete life history events in the model, and white rectangles with dashed lines are stochastic parameters in the model. Dashed black lines linking nodes indicate connections between stochastic parameters and other model components. Grey arrows indicate direction of information flow in the model. 
1298 1299

Fig. 4. Flow chart depicting location of simulated fish during a daily time-step in the individualbased model used for upstream migration of American shad. The process depicted was run each year for each day $t$ over the entire duration of the spawning run for each fish $i$. The model allowed for three outcomes: i) fish did not move upstream due to environmental or physical constraints, ii) fish did not move upstream due to failed passage and incurred a unit of delay (1 day in this case), or iii) fish moved a number of river kilometers (rkm) given successful passage and environmental and physical conditions permitting movement. A maximum daily movement ( Real $_{\mathrm{i}}$, in rkm) for each fish was simulated based on $L_{\mathrm{F}}$, tortuosity (tort), motivation, and photoperiod (see text). On each day, the individual-based model was terminated at the maximum daily movement for each fish if the fish successfully moved the maximum distance.

Fig. 5. Simulated temperature in the Penobscot River, ME, based on random sampling from multivariate normal distributions accounting for correlations between days and years. Grey lines indicate 40 simulated temperature regimes. Thin, black lines represent historical temperature data (2007-2014), and the thick, grey line represents the mean of simulated temperatures.

Fig. 6. Projected population size of American shad arriving at the mouth of the Penobscot River, Maine, during 50-year period following the implementation of the no passage (bottom panel) and no dam (top panel) scenarios. The solid line is the mean, and the dashed lines indicate 95 \% CI. Transparent grey lines are projected population abundance for 700 model runs. Note that the y-axes are presented on different scales to facilitate 
visualization, but that mean abundance from the no dam scenario is an order of magnitude larger than the no passage scenario.

Fig. 7. Proportion of spawning population in each production unit (PU) of the Penobscot River during all 50 years of simulation. Dark, horizontal lines indicate median, box ends represent inner quartile range, and whiskers are 99\% CI. Upstream and downstream passage performance standards at all dams in the catchment were set to 1.00 , with a time-frame for passage of $24 \mathrm{~h}$ (top) or $48 \mathrm{~h}$ (bottom). Production units are defined as in Table 1. Production units 1A and 2A were combined because there was no migratory barrier between them.

Fig. 8. Proportion of repeat spawners at each age for American shad in the Penobscot River after 41-50 years. Dark, horizontal lines indicate median, box ends represent inner quartile range, and whiskers are 99\% CI. Upstream and downstream passage performance standards at all dams in the catchment were set to 1.00, with a time-frame for passage of $24 \mathrm{~h}$ (top) or $48 \mathrm{~h}$ (bottom).

Fig. 9. Mean abundance of spawning American shad at the mouth of the Penobscot River (top panel) and reaching PU 5A upstream of Weldon Dam (bottom panel) during years 4150 of simulation compared to upstream and downstream passage performance standards with $24 \mathrm{~h}$ (left) and $48 \mathrm{~h}$ (right) passage times. The dotted line in the top two plots indicates interim recovery target of 633000 adult fish. 
1344 Fig. 10. Proportion of repeat spawning, age-6 American shad returning to the Penobscot River during years 41-50 of simulation compared to upstream and downstream passage performance standards with $24 \mathrm{~h}$ (left) and $48 \mathrm{~h}$ (right) passage times. Only age-6 American shad are shown because this age class represented the median age of repeat spawners in the population. The dashed, black line arbitrarily indicates a proportion of 0.30 repeat spawners as a point of reference. 
Fig. 1. Map showing the location of the Penobscot River in Maine, USA (small inset), potential spawning range of American shad following implementation of the Penobscot River Restoration Project (PRRP), and locations of dams. Dams are shown as black bars across the river, and numbers in parentheses indicate the river kilometer $(\mathrm{rkm})$ of each dam. Production units (PUs, delineated by dams) are labeled for each reach of the river from downstream to upstream, corresponding to habitat delineations in Table 1. Digital map sources include ESRI Canada (provinces and territories of Canada), United States Census Bureau (USA cartographic boundary shapefiles), and the United States Geological Survey (National Hydrography Dataset $[\mathrm{NHD}])$. 
Schematic representation of American shad production units (PUs) within the Penobscot River catchment provided in Table 1 , and migratory routes for upstream and downstream migration ( $\mathrm{i}$, ii, iii, and iv) based on the locations of dams in the river. Circles representing production units are proportional to estimated production potential (MDMR 2009) on a log-10 scale. 
Life-history diagram for American Shad showing schematic representation of modeling approach. Solid white boxes are discrete life history events in the model, and white rectangles with dashed lines are stochastic parameters in the model. Dashed black lines linking nodes indicate connections between stochastic parameters and other model components. Grey arrows indicate direction of information flow in the model. 
Flow chart depicting location of simulated fish during a daily time-step in the individual-based model used for upstream migration of American shad. The process depicted was run each year for each day $t$ over the entire duration of the spawning run for each fish $i$. The model allowed for three outcomes: i) fish did not move upstream due to environmental or physical constraints, ii) fish did not move upstream due to failed passage and incurred a unit of delay (1 day in this case), or iii) fish moved a number of river kilometers (rkm) given successful passage and environmental and physical conditions permitting movement. A maximum daily movement (dReali, in rkm) for each fish was simulated based on LF, tortuosity (tort), motivation, and photoperiod (see text). On each day, the individual-based model was terminated at the maximum daily movement for each fish if the fish successfully moved the maximum distance. 
Simulated temperature in the Penobscot River, $M E$, based on random sampling from multivariate normal distributions accounting for correlations between days and years. Grey lines indicate 40 simulated temperature regimes. Thin, black lines represent historical temperature data (2007-2014), and the thick, grey line represents the mean of simulated temperatures. 
Projected population size of American shad arriving at the mouth of the Penobscot River, Maine, during 50-year period following the implementation of the no passage (bottom panel) and no dam (top panel) scenarios. The solid line is the mean, and the dashed lines indicate 95 $\%$ CI. Transparent grey lines are projected population abundance for 700 model runs. Note that the $y$-axes are presented on different scales to facilitate visualization, but that mean abundance from the no dam scenario is an order of magnitude larger than the no passage scenario. 
Proportion of spawning population in each production unit (PU) of the Penobscot River during all 50 years of simulation. Dark, horizontal lines indicate median, box ends represent inner quartile range, and whiskers are $99 \%$ CI. Upstream and downstream passage performance standards at all dams in the catchment were set to 1.00 , with a time-frame for passage of 24 $\mathrm{h}$ (top) or $48 \mathrm{~h}$ (bottom). Production units are defined as in Table 1. Production units $1 \mathrm{~A}$ and $2 \mathrm{~A}$ were combined because there was no migratory barrier between them. 
Proportion of repeat spawners at each age for American shad in the Penobscot River after 41-50 years. Dark, horizontal lines indicate median, box ends represent inner quartile range, and whiskers are $99 \%$ CI. Upstream and downstream passage performance standards at all dams in the catchment were set to 1.00 , with a time-frame for passage of $24 \mathrm{~h}$ (top) or $48 \mathrm{~h}$ (bottom). 
Mean abundance of spawning American shad at the mouth of the Penobscot River (top panel) and reaching PU 5A upstream of Weldon Dam (bottom panel) during years 41-50 of simulation compared to upstream and downstream passage performance standards with 24 $\mathrm{h}$ (left) and $48 \mathrm{~h}$ (right) passage times. The dotted line in the top two plots indicates interim recovery target of 633000 adult fish. 
Proportion of repeat spawning, age- 6 American shad returning to the Penobscot River during years 41-50 of simulation compared to upstream and downstream passage performance standards with $24 \mathrm{~h}$ (left) and $48 \mathrm{~h}$ (right) passage times. Only age-6 American shad are shown because this age class represented the median age of repeat spawners in the population. The dashed, black line arbitrarily indicates a proportion of 0.30 repeat spawners as a point of reference. 